"This is an Accepted Manuscript of an article published by Taylor \& Francis in Information \& Communications Technology Law, 24:2, 121163, on 16 February 2016, available online: https://doi.org/10.1080/13600834.2015.1004244 


\title{
Analysis of TRIPS Agreement and the Justification of International IP Rights Protection in the WTO's Multilateral Trading System, with Particular Reference to Pharmaceutical Patents
}

\author{
Jae Sundaram*
}

\begin{abstract}
The entry of the TRIPS Agreement has seen the developing countries and the least developed countries (LDCs) suffer from the excessive burden of obligations imposed under the Agreement to embrace and implement a higher standard of intellectual property protection. One of the areas where the impact of the measures are most felt is on accessibility to affordable medicines for frontline treatment of diseases in developing countries and LDCs, where the majority of the HIV/AIDS sufferers come from. This inevitable plight, although well known, and posited by the developing countries and LDCs during the Uruguay round of negotiations, was overlooked. This also necessitated the Doha Deceleration, which does not seem to have addressed the problem. The developed countries have also successfully utilised the TRIPS Agreement's intellectual property rights protection criteria as a benchmark, to develop a much higher intellectual property rights protection agenda through the introduction of TRIPS-plus provisions in bilateral and other plurilateral agreements entered into with developing countries. The winners in the game are the patent holding pharmaceutical corporations, software corporations, media corporations, and the developed countries where they are incorporated. The one at the receiving end are the developing countries and the LDCs who were promised technology transfer to build a modern economy by the developed countries, but are faced with multiple problems of non-availability of affordable medicines for health care, besides others. This article seeks to study the justification for an extended intellectual property rights protection under the TRIPS Agreement through an analysis of the philosophical underpinnings of the intellectual property rights and the patent regime. It will be argued that the TRIPS Agreement is a major obstacle that the developing countries and the LDCs have been made to face as Members of the WTO, with no end in sight for their miseries, and that the only possible solution is a review, or amendment of the TRIPS Agreement.
\end{abstract}

Keywords: TRIPS-Flexibilities; pharmaceutical-patents; Economic-Analysis; Access-tomedicines; Human-Rights; WTO-Principles

\section{PART 1}

\section{Introduction: TRIPS Agreement}

The Trade-Related Aspects of Intellectual Property Rights (TRIPS) Agreement was introduced through the World Trade Organization (WTO) in January 1995. The TRIPS Agreement is viewed as the most important instrument in the vision for a global governance of IP rights protection, and is one of the most controversial agreements of the multilateral trading system. The expansion of International intellectual property rights protection through the TRIPS Agreement has presented the developing countries and least developed countries

*Senior Lecturer in Law, Law School, University of Buckingham. Email: jae.sundaram@buckingham.ac.uk. 
(LDCs) with hitherto unknown challenges in various fields including health care, and agriculture. The introduction of the Agreement has witnessed an exponential price rise of life saving drugs, and has created barriers in the access to affordable medicines in developing countries and LDCs. This price rise has also severely impacted on national commitments to health care and other welfare programmes. The flexibilities contained in the TRIPS Agreement have not been fully utilised by the developing countries and LDCs due to a number of reasons. In some cases lobbying by transnational pharmaceutical corporations and political reasons had caused the delays in the implementation, and in some other cases the introduction of TRIPS-plus provisions in Free Trade Agreements (FTAs) by developed countries had thwarted the introduction of such flexibilities.

The TRIPS Agreement, which has far-reaching implications on international intellectual property rights protection, was drafted at the behest of patent right holders and strongly backed by developed countries. ${ }^{1}$ The Agreement sets a minimum standard for the protection of intellectual property rights and obligates, both developed and developing country Member States to grant product patents for a period of 20 years in all fields of technology, including pharmaceutical patents. ${ }^{2}$ It requires all Member States to comply with pre-existing international agreements on intellectual property, ${ }^{3}$ and also to afford equal treatment to citizens of all other Member States. ${ }^{4}$ The Agreement, to ensure effective protection to both domestic and international patent holders' rights, requires all Member States to establish enforcement mechanisms both domestically, and at their national borders. ${ }^{5}$ The WTO Member States are also obligated to introduce domestic intellectual property laws establishing minimum levels of protection for the intellectual property rights identified in the Agreement, subject to transitional arrangements. ${ }^{6}$ In effect, the Agreement has globalised intellectual property rights, despite the profound asymmetries existing amongst WTO Member States in their levels of scientific and technological development. ${ }^{7}$ The Agreement expressly addresses private rights of economic operators (intellectual property rights holders), unlike the GATT and other WTO agreements, which formally grant rights to Member States and only address rights of traders indirectly. ${ }^{8}$ While the Agreement creates new rights for producers of intellectual property, and obligations for the users and consumers, it barely

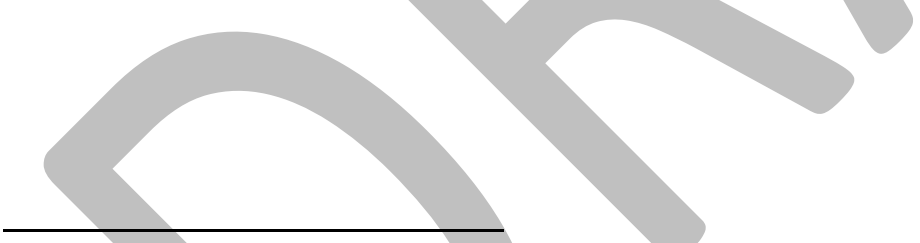

\footnotetext{
${ }^{1}$ See generally, SK Sell, Private Power, Public Law: The Globalization of Intellectual Property Rights, Vol. 88 (Cambridge University Press, 2003).

${ }^{2}$ Under the Paris Convention for Protection of Industrial Property 1883, contracting parties were permitted to exclude patent protection in certain sectors such as pharmaceuticals, and permitted to determine the duration of patent rights, and grant compulsory license for a variety of reasons. Most of these flexibilities are not available under the TRIPS Agreement.

${ }^{3}$ For instance, The Paris Convention for the Protection of Industrial Property 1883 (as revised on 14 July 1967), and The Berne Convention for the Protection of Literary and Artistic Works 1886.

${ }^{4} \mathrm{CM}$ Ho, 'An Introduction to TRIPS' in CM Ho, Access to Medicine in Global Economy: International Agreement on Patents and Related Rights (Oxford, 2011) 57.

5 J Sundaram, 'Brazil's Implementation of TRIPS Flexibilities: Ambitious Missions, Early Implementation, and the Plans for Reform' Information \& Communications Technology Law Vol. 23 Issue 2 (2014) 81-116.

${ }^{6}$ Part VI of the TRIPS Agreement provides for Transitional Arrangements under Article 65 and Article 66 with respect to developing countries and LDCs respectively.

${ }^{7}$ See generally, CM Correa, Trade Related Aspects of Intellectual Property Rights (Oxford, 2007).

${ }^{8}$ T Cottier, 'The Agreement on Trade-Related Aspects of Intellectual Property Rights' in PFJ Macrory, AE Appleton, and MG Plummer (eds) The World Trade Organisation: Legal Economic and Political Analysis Vol. I (Springer, New York, 2005) 1041-1122, 1043.
} 
speaks about the rights of the users of intellectual property, ${ }^{9}$ which is uncharacteristic of an international agreement created and administered by a world governing body. ${ }^{10}$

The Agreement also fully incorporates substantive rules enshrined in other international agreements and Conventions previously administered by the World Intellectual Property Organization (WIPO). ${ }^{11}$ Interestingly, the international Conventions administered by the WIPO were only focused on laying down procedures to streamline patent applications in countries already granting patents, and to ensure the equal treatment of both foreign and domestic patent applications. ${ }^{12}$ The Agreement does not strive to achieve uniformity in international intellectual property laws, ${ }^{13}$ and it often leaves undefined the minimum standards to be followed by Member States, creating room for variations in national legislations. ${ }^{14}$ Not surprisingly, the inclusion of international IP protection through the TRIPS Agreement was vehemently opposed during the Uruguay Round of Negotiations by both developing countries and LDCs. The TRIPS Agreement's advantages and disadvantages have been discussed in detail in a number of scholarly works, where it has been argued by some that a global intellectual property rights protection regime under the TRIPS Agreement poses a serious threat, or barrier, in achieving the goal of access to medicines both in developing countries and UDCs. ${ }^{15}$ Other serious criticisms to emerge are with regards to the GATT for including an international intellectual property protection in the agenda for negotiation in the Uruguay Round, ${ }^{16}$ and also the shortcomings and the failure of the negotiation process in not fully appreciating the opposition to the inclusion of intellectual property rights in the Uruguay round of GATT. ${ }^{17}$

This article analyses the TRIPS Agreement from a select few perspectives to include the study of the benefits of the Agreement under economic law principles; seek justification from a human rights perspective to the question if it was wise to equate private rights of pharmaceutical patent right holders with access to medicine, especially when there was an overwhelming body of evidence that the implementation of the TRIPS Agreement will see the price of essential drugs rise exponentially; and if there was a level playing field in the negotiations when many member countries did not even have elementary levels of intellectual property standards due to weaknesses in the national economy, knowledge economy, and

\footnotetext{
${ }^{9}$ See, e.g., A Kur and HG Ruse-Khan, 'Enough is Enough - The Notion of Binding Ceilings in International Intellectual Property Protection' Max Planck Institute for Intellectual Property, Competition \& Tax Law, Research Paper Series No. 09-01, (2008) <http://ssrn.com/abstract=1326429> accessed 13 May 2014.

${ }^{10}$ Sundaram (n 5).

${ }^{11}$ Cottier (n 8). See also UNCTAD-ICTSD, 'Resource Book on TRIPS and Development' (2005) 3. Before the entry into force of the TRIPS Agreement, international intellectual property rights were regulated through a patchwork of treaties administered by the World Intellectual Property Organization (WIPO), including the Paris Convention on Industrial Property 1883, and the Berne Convention on Literary and Artistic Works 1886. See also Sundaram (n 5).

${ }^{12}$ The Paris Convention for the Protection of Industrial Property, Article 3, 20 March 1883, revised 14 July 1967, 21 UST 1583, 828 UNTS 305 (requiring equal treatment for foreign applicants); Patent Cooperation Treaty, 19 June 1970, 28.7 UST 7645, 1160 UNTS 232 (providing a streamlined process for submitting patent applications in multiple jurisdictions). National treatment under the Paris Convention, however, does not require Member States to provide any particular standard of protection, but the same level of protection provided to domestic work also be provided to foreign works. DG Richards, Intellectual Property Rights and Global Capitalism: The Political Economy of the TRIPS Agreement (ME Sharpe, 2004) 4; See also Ho (n 4).

${ }^{13}$ Correa (n 7). The author argues that the Agreement does not set forth a uniform law on intellectual property, but only proposes minimum standards which may be differently implemented in Member States.

${ }^{14}$ Sundaram (n 5).

${ }^{15}$ Sell (n 1).

${ }^{16}$ P Drahos, 'Expanding Intellectual Property's Empire: The Role of FTAs' Regulatory Institutions Network, Research School of Social Sciences, Australian National University (2003).

${ }^{17}$ Ibid.
} 
infrastructure. This article is divided into four parts, with the first part presenting the introduction to the TRIPS Agreement and the premise of the current research, the second part providing the background to the entry of international intellectual property rights enforcement into the WTO through extensive lobbying from pharmaceutical patent holders from developed countries, which was ably supported by the music and motion picture industry and the software industry, to move the administration of intellectual property rights enforcement from the WIPO to the WTO. The discussions will include the failed attempts of the developing countries and LDCs to prevent the introduction of international intellectual property right protection as a covered agreement under the WTO, and the measures taken to introduce TRIPS flexibilities and the passing of the Doha Declaration.

The second part will also briefly outline the background to the introduction of intellectual property rights in the former colonies during the colonial era, which largely facilitated the implementation of an expanded intellectual property rights regime through the TRIPS Agreement. The third part will analyse the emergence of intellectual property rights and the legal justification in the 17th century, the philosophical and legal basis of modern intellectual property rights under the economic law principles to argue that it benefits only a handful of rights holding developed Member States of the WTO, while depriving the nonrights holding Member States of any benefits. The third part will also closely analyse the TRIPS Agreement from a human rights perspective, and its impact on access to medicines in developing countries and LDCs. It will be argued that the international intellectual property rights protection regime, as it stands today, does not benefit and cannot benefit the developing countries and the LDCs, that it is primarily designed to benefit the rights holders and not the end users in developing countries and LDCs as it comes at a very high premium, and that any potential benefits to be derived from the regime is too onerous. The fourth part will discusses the findings and conclude, making suggestions as a way forward for the WTO community, including a complete rethink of the TRIPS Agreement, if not, a comprehensive review.

\section{PART 2}

\subsection{Forum Shifting: Inclusion of Intellectual Property Rights Protection in the WTO}

The vision for an international intellectual property rights protection was initially conceived and promoted by patent rights holding transnational corporations from developed countries, which had campaigned relentlessly for the inclusion of an agreement on intellectual property rights in the Uruguay Round of Multilateral Trade Negotiations. ${ }^{18}$ It was claimed by US industries, which included pharmaceutical corporations, that they suffered heavy losses from the absence of adequate protection of their intellectual property rights in foreign markets. ${ }^{19}$ A strong view exist amongst writers, that some twelve US corporations were primarily responsible for the lobbying that brought the TRIPS Agreement into existence. ${ }^{20}$ The TRIPS Agreement came to be an output of private nodal governance, ${ }^{21}$ with the process starting in the 1980s when one of the transnational pharmaceutical corporations

\footnotetext{
${ }^{18}$ Drahos (n16).

19 AO Adede, 'Origins and History of the TRIPS Negotiations' in G Dutfield, Trading in Knowledge: Development Perspectives on TRIPS, Trade and Sustainability (ICTSD/Earthscan 2003) 23-35, 24.

20 Sell (n 1); P Drahos and J Braithwaite, Information Feudalism: Who Owns the Knowledge Economy? (Earthscan 2002); D Matthews, Globalising Intellectual Property Rights (Routledge 2002).

${ }^{21}$ Drahos (n 16). See also R Weissman, 'A Long, Strange TRIPS: The Pharmaceutical Industry Drive to Harmonize Global Intellectual Property Rules, and the Remaining WTO Legal Alternatives Available to Third World Countries,' U Pa J Int'l Econ L 17 (1996) 1069-1125, 1076.
} 
took the lead in creating an agenda to include US intellectual property rights protection abroad. ${ }^{22}$ The pharmaceutical industry engaged in aggressive lobbying campaigns on the need to secure greater patent protection abroad, and also through funding academic studies aimed at proclaiming the merits of patent protection. ${ }^{23}$ The US pharmaceutical industry's principle argument was that anything less than an American-style patent protection would constitute stealing by other nations. ${ }^{24}$ The industry's strategy was therefore, to persuade US policy makers to coerce Third World/developing countries to introduce restrictive patent laws into their domestic legislation. ${ }^{25}$ Needless to say, the lobbying was a great success, and the US government in the 1980 s started introducing suitable provisions protecting intellectual property as an investment activity in the Bilateral Investment Treaty (BIT) program, which it was negotiating with developing countries during that time. ${ }^{26}$ The US pharmaceutical industry also succeeded in making strict international protection of intellectual property rights a central goal of US international economic policy. ${ }^{27}$ The then US President Reagan in a message to Congress in February 1986 proposed that a key item for consideration was to seek much greater protection of US intellectual property interest in overseas territories. ${ }^{28}$

The next step for the lobbyists was to move the discussion on international intellectual property rights protection to the GATT negotiations. In 1986, a coalition of thirteen major US corporations including Pfizer, Bristol-Meyers, Merck, and Johnsons \& Johnson, to name a

${ }^{22}$ Drahos (n 16). The author identifies the US pharmaceutical corporation, Pfizer Inc, as taking the lead in lobbying through its well established business networks to disseminate the idea of a trade-based approach to IP rights, and later on through interlinking of the networks. The author also identifies the role played by the Advisory Committee on Trade Negotiations (ACTN), which was part of a private sector advisory committee system which was to ensure concordance between official US trade objectives and US commerce, and how the CEO of Pfizer Inc, and chairman of ACTN, with the help of other like minded CEOs of leading US corporations, was able to develop a trade and investment agenda to protect US IP rights abroad.

${ }^{23}$ Weissman (n 21) 1076-1077.

${ }^{24}$ J Kosterlitz, 'Rx: Higher Prices’, National Journal, Vol. 25, No 7 (1993) 396-399.

${ }^{25}$ Ibid. Starting in 1985, the United States Trade Representative (USTR) served notice on a number of countries informing them about possible trade sanctions if they were to not bring their domestic patent laws into line with American laws. See Weissman (n 21) 1077-1078. The USTR acting under Section 301 of the Trade Act 1974, placed countries which did not provide adequate protection to US IP interests on its 'watch lists' and 'priority watch lists'. The primary targets were large Third World/developing countries like, India, Argentina, Brazil, Taiwan and Thailand, which had begun to develop domestic industries to compete against US pharmaceutical manufacturers in their own markets. See also BM Berliner, 'Making Intellectual Property Pirates Walk the Plank: Using Special 301 to Protect the United States' Rights', Loy L A Int'l \& Comp L J (1990) 725-752, 727. The US Congress, in pursuit of a more combative approach to enforcing its IP rights overseas, enacted the Omnibus Trade and Competitiveness Act (Trade Act of 1988).

${ }^{26}$ Drahos (n16). Towards this end, the Office of the USTR exerted extraordinary pressure on individual Third World countries to embrace US-style patent laws; Weissman (n 21) 1077. See also J Burgess, 'Fighting Trespassing on "Intellectual Property": U.S. Tries to Prevent Overseas Copying of Everything From Music to Microchips', Washington Post (6 December 1987). The author also notes that in 1984, a trade bill was passed by the US Congress, which included provisions for safeguarding of IP as an important consideration in granting developing countries preferential tariff treatment. See also P David, 'Intellectual Property Institutions and the Panda's Thumb: Patent, Copyrights, and the Trade Secrets in Economic Theory and History' in M Wallerstein, et al (eds.), Global Dimensions of Intellectual Property Rights in Science and Technology (National Academy Press, 1993) 20. The author observes that the United States was able to achieve considerable success in convincing developing and newly industrialized nations to acquiesce to its position on the treatment of various forms of IP with the threat of sanctions, as their retaliatory leverage was quite limited.

${ }^{27}$ Weissman (n 21) 1077. The author notes that it was a great success to move the policy in the direction of strict international IP rights protection, as traditional domain of international trade policy was primarily focused on tariff and related matters. See also C Reitz, 'Enforcement of the General Agreement on Tariffs and Trade' U Pa J Int'l Econ L 17 (1996) 559-579, 555.

${ }^{28}$ Drahos (n 16). In a message dated 6 February 1986 and entitled 'America's Agenda for the Future' President Reagan proposed that a key item was much greater protection for US intellectual property abroad. 
few, formed an ad hoc committee called Intellectual Property Committee (IPC). ${ }^{29}$ The stated objective of the committee in its own words was 'dedicated to the negotiation of a comprehensive agreement on intellectual property in the current GATT round of multilateral trade negotiations. ${ }^{30}$ WIPO, created in 1967, was the first international attempt to address some of the concerns relating to an international intellectual property rights movement. The developing countries were opposed to altering the WIPO system to strengthen intellectual property rights protection. ${ }^{31}$ WIPO, in the eyes of patent holding developed nations, was incapable of responding effectively to issues relating to intellectual property rights violation. ${ }^{32}$ Developed countries, including US, EC, and Japan acted fast to shift the global intellectual property rights administration from the WIPO to the GATT with a view to achieving the objective of an expanded international intellectual property rights protection regime. Industry groups from patent holding developed countries successfully created a coalition of governments that would pursue the objective of moving intellectual property rights regulation from WIPO to the GATT. ${ }^{33}$ The move for a global intellectual property rights protection mooted by developed countries and led by the US, was strongly opposed by developing countries including Argentina, Brazil, India, and South Africa amongst others. ${ }^{34}$ The developing countries were strongly in favour of a WIPO-led negotiation, as opposed to a revision of international intellectual property rights obligations through the GATT, as the WIPO had traditionally been the forum for such matters. ${ }^{35}$ Patent holding businesses in the US, EC and Japan, successfully exerted pressure on their respective governments to ensure that IP rights became a global commercial issue and also the focus of attention during the Uruguay Round of GATT negotiations. ${ }^{36}$

India, along with similarly placed countries like, Brazil and Argentina, strongly opposed the proposal on the premise that the GATT mandate did not allow for the discussion of substantive issues on intellectual property, and that it was only the WIPO that had the mandate and the institutional competence to discuss such matters. ${ }^{37}$ Also, most developing countries that sought membership of the WTO and entered the Uruguay round of negotiations

${ }^{29}$ Drahos (n 16). See also R Weissman, 'Patent Plunder: TRIPing the Third World', Multinational Monitor Vol. 11 (November 1990) <http://www.multinationalmonitor.org/hyper/issues/1990/11/weissman.html> accessed 7 July 2014.

${ }^{30}$ Drahos (n 16). See also Weissman (29). IPC's close relationship with the USTR permitted it to shape the US proposals and negotiating positions during the course of the GATT negotiations.

${ }^{31}$ UNCTAD-ICTSD, Resource Book on TRIPS and Development (Cambridge University Press, 2005), 3.

${ }^{32}$ L Crump and D Druckman, 'Turning Points in Multilateral Trade Negotiations on Intellectual property,' International Negotiation Vol. 17, No. 1 (2012) 9-35, 12.

${ }_{33}$ Ibid. See also Drahos (n 16); TP Stewart, The GATT Uruguay Round: A Negotiating History (1986-1992), Vol. 3 (Kluwer Law and Taxation Publishers, 1993), 1-10.

${ }^{34}$ For the role played by India on behalf of the developing countries during the negotiations, see generally, J Sundaram, 'India's Trade-Related Aspects of Intellectual Property Rights Compliant Pharmaceutical Patent Laws: What Lessons for India and Other Developing Countries?' Information \& Communications Technology Law Vol. 23 Issue 1 (2014) 1-30.

${ }^{35}$ C Edgar, 'Patenting Nature: GATT on a Hot Tin Roof', Washburn L J, Vol. 34 (1994) 76-118. See also Weissman (n 21) 1083. See also Weissman (n 29). The developing countries were distrustful of GATT, which was largely constructed by, and dominated by industrialized countries. They favoured discussing IP rights protection before United Nations-affiliated organizations, such as the WIPO, where the Third World countries exerted greater influence.

${ }^{36}$ D Matthews, Globalising Intellectual Property: The TRIPS Agreement (Routledge, 2001) 7.

${ }^{37} \mathrm{~J}$ Watal, Intellectual Property Rights in the WTO and Developing Countries (Kluwer Law International, 2001)

21. See generally P Drahos, 'Developing Countries and International Intellectual Property Standard-Setting', The Journal of World Intellectual Property Vol. 5 No 5 (2002) 765-789. 
were not granting patent monopolies for pharmaceuticals. ${ }^{38}$ India's position, which was well supported by other developing countries, was that any principle or standard relating to intellectual property rights was to be carefully tested against the needs of developing countries, and that it would be inappropriate to focus the negotiations on the protection of monopoly rights of the owners of intellectual property rights, when almost $99 \%$ of the patents were owned by industrialised nations. ${ }^{39}$ Throughout the TRIPS negotiations, the US maintained a firm stance towards reaching a global agreement for higher levels of intellectual property rights protection. This position, essentially calling for the world to adopt a US-style patent law was developed largely by the pharmaceutical industry; according to the industries' own admission. ${ }^{40}$ Although India's position was discussed extensively at the negotiations, by the end of 1989 and the beginning of 1990 the developing countries were constrained to change their position completely, paving the way for a US-style intellectual property rights protection to be imposed through the GATT, ${ }^{41}$ thereby circumventing and undermining the authority of the WIPO. The long-drawn Uruguay round of negotiations produced the TRIPS Agreement, which came into force in January 1995. The Agreement can be viewed as the most important step in the globalization of standards of patent, trade secrets and trademark protection, the three areas most relevant to the success of chemical and pharmaceutical companies. ${ }^{42}$ Of major significance was the obligation on Member States to make available patents for products and processes without discrimination as to the field of technology, ${ }^{43}$ and requiring the introduction of product patents for chemical and pharmaceutical patents.

\subsection{The TRIPS Agreement: Flexibilities and the Doha Declaration}

The TRIPS Agreement which came into force on 1 January 1995, allows Member States to provide for a more extensive protection of intellectual property right if they wish to, and a minimum standard of protection from others who may not favour the idea of an extensive protection. ${ }^{44}$ The Agreement also contains flexibilities in its implementation, which is particularly aimed at developing countries and LDCs. A number of scholarly articles have been written on the subject of flexibilities contained in the TRIPS Agreement and the WTO's failure to address the problem of the access to medicines in developing countries and LDCs. The patent-related flexibilities identified include provision for grant of compulsory licensing, parallel importation, and provisions relating to patentable subject matter, patent rights, abuse

${ }^{38}$ CM Correa, 'Patent Rights' in CM Correa and AA Yusuf (eds), Intellectual Property and International Trade: The TRIPS Agreement (2nd edn, Kluwer, 2008) 227, 229.

${ }^{39}$ UNCTAD-ICTSD (n 31) 7. India also stressed that substantive standards on IP rights were more in the realm of socio-economic and technological development, especially in the case of developing countries. It urged that the group focus on restrictive and anti-competitive practices of the owners of IP rights to evolve standards and principles for their elimination and to avoid distortion of trade. See Sundaram (n 34) 8.

${ }^{40}$ Weissman (n 21).

${ }^{41}$ See also SK Sell, 'Cat \& Mouse: Forum-Shifting in the Battle over Intellectual Property Enforcement' (Draft, prepared for American Political Science Association Meeting, 3-6 September, 2009, Toronto) $<$ http://papers.ssrn.com/sol3/papers.cfm?abstract_id=1466156> accessed 9 July 2014. See also C Deere, The Implementation Game: The Global Politics of Intellectual Property Reform in Developing Countries (OUP, 2009) 53. In the mid-1980s, developing countries faced pressures from both developed countries and knowledge-based multinational companies to agree to the inclusion of a stringent international IP commitment in the multilateral trading system. To break the standoff, developed countries also launched an economic and diplomatic offensive that ultimately forced developing countries to concede.

42 Drahos (n 16).

${ }^{43}$ See Article 27.1 of TRIPS.

44 World Intellectual Property Organization, 'Patent Related Flexibilities in the Multilateral Legal Framework And Their Legislative Implementation at the National and Regional Levels,' Committee on Development and Intellectual Property, Fifth Session, WIPO (26-30 April 2010). 
of rights, and the control of anti-competitive practices. ${ }^{45}$ Some of the other flexibilities identified by commentators include the exhaustion of rights ${ }^{46}$ and parallel importation, scope of patentability and optional exclusion, exceptions to patent rights and enforcement. ${ }^{47}$ Some developing countries feared that the extended intellectual property rights protection granted for pharmaceutical patents under the Agreement was likely to increase dependency on multinational pharmaceutical companies and affect the developing countries and LDCs severely, as essential medicines could become unaffordable and beyond their reach. ${ }^{48}$ The developing countries were fully aware that the patent holding developed countries, which advocated a wider global intellectual property rights protection and promoted the TRIPS Agreement, had a strong public health care system and would not be affected by the pharmaceutical patent regime of the Agreement.

The US and Switzerland (both holding a number of pharmaceutical patents), and well supported by other developed countries, took the stance that the only flexibility afforded under the Agreement was its staggered implementation in certain cases, but in contrast the developing countries were of the firm view that the TRIPS Agreement did not limit their sovereign powers when addressing domestic health crises, such as HIV/AIDS. ${ }^{49}$ In short, the impact of the TRIPS Agreement on public health in developing countries and LDCs became a serious issue. Due to growing pressure from the developing countries, and in particular from the Member States from Africa, the Council for TRIPS ${ }^{50}$ in June 2001 considered in detail the relationship between public health and TRIPS Agreement. ${ }^{51}$ In November 2001, the Doha Declaration on TRIPS and Public Health ${ }^{52}$ (Doha Declaration) was made, addressing some of

45 SF Musungu and $\mathrm{C} \mathrm{Oh}$, 'The Use of Flexibilities in TRIPS by Developing Countries: Can They Promote Access to Medicines?' South Center (2006). The authors study the TRIPS flexibilities from the perspective of access to affordable medicines.

46 The 'exhaustion of patent rights' is sometimes referred to as the 'first-sale' doctrine. The TRIPS Agreement under Articles 6 and 28(6), and the Doha Declaration under Article 5 (d) allow Member States to determine the scope and extent of exhaustion of patent rights. This position is strongly disputed by the US Delegation to the Council of TRIPS, as it holds the view that Article 6 of the TRIPS Agreement neither allows WTO Members to avail themselves of dispute settlement in relation to questions involving parallel imports, nor authorised parallel imports (Delegation of the United States, Council for TRIPS Meeting of June 1822, 2001, JOB(01)/97/Add.5, Council for TRIPS, 28 June 2001). See also WIPO (no 44); CM Correa, 'The TRIPS Agreement and Developing Countries' in PJ Macrory and others (eds.), The World Trade Organisation: Legal, Economic and Political Analysis Vol. II (Springer, 2005) 447.

${ }^{47}$ Deere (n 41) 75. The author suggests the development of national policies on utility models, disclosure of origin of genetic material and prior informed consent, and traditional knowledge (folklore and cultural heritage were also mentioned).

48 Sundaram (n 5) 5. Access to essential medicines is recognised as an indispensable part of the right to health and is viewed as a non-delegable obligation on the part of the State, and cannot be violated based on lack of available resources. 'The Selection and Use of Essential Medicines' WHO Technical Report Series 914 (2002) $<$ http://apps.who.int/medicinedocs/pdf/s4875e/s4875e.pdf $>$ accessed 9 July 2014. The developing countries and the LDCs were apprehensive that the TRIPS Agreement if given effect to could severely restrict access to essential medicines within their jurisdictions and also impede any efforts to control diseases, including HIV/AIDS, tuberculosis and malaria.

${ }^{49}$ Sundaram (n 39).

50 The legal basis for the establishment of the Council is found in Article IV.5 of the WTO Agreement, which stipulates that the Council 'shall oversee the functioning' of TRIPS Agreement. The Council for TRIPS is also charged with the monitoring of WTO Members' compliance with their obligations under the TRIPS Agreement. See also UNCTAD-ICTSD (n 10) 739.

${ }^{51}$ In 1996 the World Health Assembly, which was mandated to report on the impact of the work of the WTO with respect to national drug policies and essential drugs, examined the relationship between public health and the TRIPS Agreement. See resolution on the Revised Drug Strategy, Resolution WHA 49.14 (25 May 1996).

${ }^{52}$ World Trade Organization, Declaration on the TRIPS Agreement and Public Health, WT/MIN(01)/DEC/2, adopted on 20 November $2001<\mathrm{http}$ //www.wto.org/english/thewto_e/minist_e/min01_e/mindecl_trips_e.pdf> accessed 9 July 2014. The Doha Declaration, besides providing interpretative guidance on the policy of 
the concerns of the developing countries, which also sought to clarify other divergent views, held by the Member States on the application and ambit of the TRIPS Agreement. ${ }^{53}$ Under the Doha Declaration, the Member States had the right to grant compulsory licences, to determine the grounds for the grant, and also as to what constituted a national emergency. ${ }^{54}$ Some developing countries have made constructive use of the TRIPS flexibilities while giving effect to the TRIPS Agreement into their national legislations. Some countries have delayed the introduction of product patents into their legislation, ${ }^{55}$ and others have used the compulsory licensing provisions to manufacture or procure generic medicines at an affordable price. ${ }^{56}$ It will not be out of place to point out that the implementation of flexibilities in key pharmaceutical markets like, Brazil, India, and South Africa came at a very high price, as transnational pharmaceutical corporations, well supported by developed country participation, were able to mount oppositions and cause delays in the actual implementation. ${ }^{57}$

\subsection{Expansion of Intellectual Property Laws: The Haunting Colonial Legacy}

Intellectual property rights, which evolved in the Middle Ages ${ }^{58}$ was introduced by the industrialised colonial powers into their respective colonies and dominions from the 19th century. It will be beneficial for the purposes of the current study to cast our thoughts backwards in time to understand the role of colonialism in the expansion of intellectual property laws (industrial property, copyrights, and trademarks) in the 19th century in the former colonies. ${ }^{59}$ Some of the difficulties in accessing affordable medicines in the

flexibilities embodied in the TRIPS Agreement, also helped clarify the scope of the TRIPS Agreement. See UNAIDS, 'DOHA+10 TRIPS Flexibilities and Access to Antiretroviral Therapy: Lessons from the Past, Opportunities for the Future', UNAIDS: Technical Brief, (ISBN: 978929173914, 2011) 6.

${ }^{53}$ JT Gathii, 'The Legal Status of Doha Declaration on TRIPS and Public Health under the Vienna Convention on the Law of Treaties' Harv JL Tech, Vol. 15 (2002) 291-317, 292-293.

${ }^{54}$ The 2001 Doha Declaration, and the 2003 Decision on Implementation of Paragraph 6 of the TRIPS Agreement recognises the right of a country to gain access to medicines. See, Council WTO General, 'Implementation of Paragraph 6 of the Doha Declaration on the TRIPS Agreement and Public Health,' Decision of the General Council [WT/L/540 and Corr.1] (1 September 20032003).

${ }^{55}$ India, one of the developing countries, has made maximum use of the flexibilities. India was able to delay the entry of the product patent regime into its patent laws, and ably support its generics market which was developed on the back of the process patent regime introduced in the Patent Act of 1970. Besides, in recent years India has also made use of the compulsory licensing provision introduced in TRIPS compliant legislation of 2005. For a detailed account see Sundaram (n 39).

${ }^{56}$ Brazil, one of the BRIC nations, which introduced the TRIPS compliant patent laws into its national legislation much earlier than others, was able to use the compulsory license provisions under the TRIPS compliant legislation to procure generic medicines at affordable prices for its much lauded anti-AIDS programme. For a detailed account see Sundaram (n 5).

57 See generally Sundaram (n 5); Sundaram (n 39). See also, P Drahos and J Braithwaite, Information Feudalism: Who Owns the Knowledge Economy? (Earthscan, London 2002) 6-8. Transnational pharmaceutical corporations took legal action against the government of South Africa for its proposed compulsory licensing laws.

${ }^{58}$ CM Correa, 'Managing the Provisions of Knowledge: The Design of Intellectual Property Laws', in I Kaul, et al (eds.), Providing Public Goods: Managing Globalization (Oxford, 2003) 410. See F Machlup and E Penrose, 'The Patent Controversy in the Nineteenth Century,' The Journal of Economic History, Vol. X, No. 1 (1950) 129, 2. The authors observe that apart from its expression in statute form (Statute of Monopolies of 1623), the patent system is not chiefly an English creation, as there was a rather well-developed patent system in existence in Venice in the 15th century, and the practice of granting monopoly privileges to inventors was widely followed in many parts of western and central Europe in the 16th and 17th centuries.

${ }^{59}$ Deere (n 47) 35. Britain introduced its then prevailing laws (including IP laws) in its colonies. Likewise, France too applied its own IP laws to its colonies. See also RL Okediji, 'The International Relations of Intellectual Property: Narratives of Developing Country Participation in the Global Intellectual Property System', Sing J Int'l \& Comp L 7 (2003) 315-385, 316. The author provides an insight by observing that when 
developing countries are still rooted in the colonial past, especially in the realm of intellectual property laws introduced during the colonial-era. The international movement on intellectual property standards started in the 19th century from developed countries to developing countries or from key industrialised Western States to developing countries/former colonies. $^{60}$ The intellectual property laws introduced during the colonial era embodied concepts alien to many traditional and indigenous approaches to knowledge and innovation, as Western conceptions of privately held rights over intellectual assets had no local cultural or legal roots. ${ }^{61}$ Besides, the colonial administrators held the traditional laws of their dominions in low regard, as they did not serve the commercial interests of the colonizers. ${ }^{62}$

The intellectual property laws introduced, or rather imposed, during the colonial era was primarily designed to protect and serve the interests of colonial administrators, and purely aimed at extracting wealth from the colonies rather than seeking to educate or promote knowledge in the colonies. Britain, during the colonial era, was keen to emphasise the promotion of the legal profession in its colonies to generate an English legal culture, but this practice was rarely extended to the realm of intellectual property laws. ${ }^{63}$ Following their independence from colonial rule, most developing countries in Africa chose to retain the legal system, the laws, and the institutions of governance established during the colonial era by the colonial powers, including intellectual property laws. ${ }^{64}$ In most of the former colonies, the establishment of national intellectual property laws only started in the wake of independence from colonial rule. ${ }^{65}$ In the Americas, and in some of the former Asian colonies, the era of decolonization also sparked efforts to substantially revise their intellectual property laws and related policies. ${ }^{66}$ A number of countries that emerged from colonial rule in the 20th Century promulgated intellectual property laws that still closely resembled earlier colonial laws or those of the erstwhile colonial powers. ${ }^{67} \mathrm{~A}$ few former colonies like India, moved towards a

the Paris Convention for the Protection of Industrial Property was concluded in 1883, the respective colonial masters swept non-Western societies in Africa and Asia under the aegis of the international intellectual property system through the agency of colonial rule. The author also notes that despite a limited membership to the Paris Convention of 1883 and the Berne Convention of 1886 by developed countries, the colonies and foreign territories controlled by a few European sovereigns made the geographic scope of the treaties significant.

${ }^{60}$ Drahos (n 37). The author refers to the case of Philippines, where Spanish patent laws were introduced, but only to be later replaced by US patent laws. Similarly in the case of Korea, Japanese patent laws were introduced, but only to be later replaced by US Patent laws. Likewise, in India and Malaysia, Britain introduced the English patent laws in the latter part of the $19^{\text {th }}$ Century and in the early part of the $20^{\text {th }}$ Century.

${ }^{61}$ Deere (n 47) 34-35.

${ }^{62}$ Okediji (n 59) 322-3; Deere (n 47) 36.

${ }^{63}$ Deere (n 47) 36. IP laws remained largely administered from London. The former colony of India was a notable exception, as Britain took measures to develop a cadre of local intellectual property law experts.

${ }^{64}$ Okediji (n 59) 335. After independence, many developing countries and LDCs continued to have as their own domestic laws the old, antiquated Acts and Ordinances of the colonial era. The author also notes that given the socio-economic conditions in most of the former colonies, existing intellectual property laws were not a reform priority as they were either beneficial to the domestic industries, or were deemed irrelevant to the domestic public.

${ }^{65}$ Deere (n 47) 35. In Latin America and the Caribbean, intellectual property laws were established in the wake of independence from the Spanish and Portuguese in the early part of the $19^{\text {th }}$ Century as opposed to the Africa, Asia and the Pacific, where intellectual property laws were introduced by colonial powers in the later part of the $19^{\text {th }}$ Century. The author points out that several countries in the Americas promulgated formal intellectual property laws far earlier than other developing countries, and indeed earlier than many developed countries.

${ }^{66}$ Deere (n 47) 39

${ }^{67}$ Deere (n 47) 37. Former British colonies enacted copyright laws based on the same 1911 British Copyright Act that served as the foundation for their colonial laws. Similarly, a number of former French colonies in Africa adopted copyright laws that replicated those of France at the given time, and some others chose to keep the laws introduced during colonial rule. See also T Kongolo, 'The African Intellectual Property Organizations: The Necessity of Adopting One Uniform System for All Africa', The Journal of World Intellectual property, 
product patent regime during the $1970 \mathrm{~s},{ }^{68}$ and as a result also emerged as a key player in the generic drugs market. In the Americas, countries like Brazil, Mexico, and Argentina lowered standards of patent protection to stimulate local production of generic medicines. ${ }^{69}$ Similarly, the Andean Community, ${ }^{70}$ comprising of former South American colonies of Chile, Colombia, Bolivia, Ecuador, and Peru followed a reformist agenda, in pursuit of a vision for industrial development and regional integration, and adopted common rules on foreign direct investment (FDI), intellectual property rights, and technology transfer. ${ }^{71}$ One can observe that in the post-colonial ear, the former colonies adopted different approaches towards their intellectual property laws and policies, where again the policies were shaped by the prevalent colonial legal system, besides other factors including social, economic and political objectives.

During the colonial era, in the latter part of the 19th Century, the two key international Conventions, viz., the Paris Convention ${ }^{72}$ and the Berne Convention ${ }^{73}$ were codified and entered into force. The two Conventions were designed to enhance the degree of protection that patent rights holders from developed countries enjoyed in overseas jurisdictions. ${ }^{74}$ With very few developing nations participating in the negotiations, only a handful became parties to the two Conventions. Interestingly, almost half of the original signatories to the Paris Convention lacked national patent regimes at the time of ratification

Vol. 3, Issue 2 (2000) 265-288, 265. The author, discussing the two major African regional IP organisations, viz., African Regional Industrial Property Organization (ARIPO) and Organisation Africaine de la Propriété Intellectuelle (OAPI), expresses the view that the systems of protection provided under the said organisations do not reflect the African realities. This, in the view of the author, is down to the fact that the organisations are modelled after the Western style of intellectual property protection which does not always correspond and fit to the African realities and environment.

${ }^{68}$ India in the 1970s moved away from the intellectual property laws introduced under British rule, based on the recommendations contained in the Justice Iyengar Committee report, and successfully introduced a process patent system as opposed to a product patent system with regards to chemical and pharmaceutical patents. But, this position was to change with its membership of the WTO and the introduction of TRIPS compliant intellectual property laws. See Sundaram (n 39); TV Garde, 'India' in P Goldstein and J Strauss (eds), Intellectual Property in Asia: Law, Economics, History and Politics (Springer, 2009). For a detailed legislative history of the Indian Patent Act, see generally, JM Mueller, 'The Tiger Awakens: The Tumultuous Transformation of India's Patent System and the Rise of Indian Pharmaceutical Innovation' (2007) 68 U Pitt L Rev 491.

${ }^{69}$ Deere (n 47) 40.

70 In 1969 the Cartagena Agreement was signed by Bolivia, Chile, Colombia, Ecuador and Peru. The objective for the Pact was the creation of a Customs Union and a Common Market. In 1996, through the Protocol of Trujillo, the Pact was renamed as the Andean Community. Venezuela joined the Pact in 1973, but under the leadership of Hugo Chavez it withdrew its membership in 2006, claiming that Free Trade Agreements (FTAs) signed by Colombia and Peru with the USA caused damage to the spirit of the community. Likewise, under the leadership of Augusto Pinochet, Chile withdrew from the Pact in 1976. Currently, it has 4 Members, 5 Associate Members, and one observer country.

${ }^{71}$ Deere (n 47) 39.

72 The Paris Convention for the Protection of Industrial Property 1883, as amended on 28 September 1979 $<$ http://www.wipo.int/export/sites/www/treaties/en/ip/paris/pdf/trtdocs_wo020.pdf > accessed 22 July 2014.

73 The Berne Convention for the Protection of Literary and Artistic Works 1883, as amended on 28 September 1979 <http://www.wipo.int/export/sites/www/treaties/en/ip/berne/pdf/trtdocs_wo001.pdf> accessed 22 July 2014.

${ }^{74}$ Deere (n 47) 36. These two treaties were also aimed at replacing the loose network of reciprocal intellectual property arrangements that European colonial powers had in place in some of the bilateral commercial treaties in the $19^{\text {th }}$ century. Notably, both the Paris and Berne Conventions enshrined the principle of National Treatment, which provides that signatory countries shall extend to foreign nationals the same advantages, rights, and legal remedies against infringement as enjoyed by their own nationals. 
of the Conventions. ${ }^{75}$ Brazil, one of the original signatory nations, and a former colony of Portugal, was an exception as it had established a patent system in the early part of the 19th Century. ${ }^{76}$ Through the mechanism contained in Article 19 of the Berne Convention, ${ }^{77}$ the former colonial powers of Britain, France, Italy, Belgium and Spain acceded their colonies to the Convention. ${ }^{78}$ The colonial powers were able to pick and choose the colonies that would be covered and the ones that would not be covered in their accession documents. ${ }^{79}$ In short, during the colonial-ear the colonies and dominions did not have a say in their accession process to the Conventions. In many cases, post-independence, the former colonies continued to be signatories without the actual need to be part of the regime, as they were mostly unaware of the necessity to have such legislations in their statute books, which were only designed to serve their former colonial masters. In the post-colonial era a number of larger developing countries were able to delay their accession to international intellectual property Conventions. ${ }^{80}$ A majority of developing countries in the Americas postponed adherence to the Paris Convention until the 1990s, as they were sceptical of the merits of intellectual property Conventions. ${ }^{81}$ In most of their former colonies and dominions, the colonial powers left behind a network of legal systems and institutions, which would in later years assist in the introduction of a more stringent intellectual property law regime, backed by the WTO, to protect the intellectual property rights interests of developed countries.

\section{PART 3}

\subsection{Intellectual Property Laws: Economic Analysis vs. Human Rights}

Economic Analysis of law presents with the affordability, and at times also the justification of a particular law to be introduced/ implemented into a legal environment. While the legislature is authorised with the responsibility to enact laws, the State has the ultimate legal obligation to oversee the implementation of laws for the governance of the

75 P Ross and G Vea, 'The WIPO Development Agenda in a Historical and Political Context,' in N. Netanel (ed.) The Development Agenda: Global Intellectual Property and Developing Countries (Oxford University Press (2008) 83. See also Deere (n 47) 37.

${ }^{76}$ Sundaram (n 5) 94; RA Brandos, 'Brazilian Patent System: A Brief Introduction' (INPI (National Institute of Industrial Property), Brazil 2012); P Drahos, The Global Governance of Knowledge: Patent Offices and Their Clients (Cambridge University Press, 2010), 242-43. Brazil, one of the original signatories to the Paris Convention had a patent regime traceable to the 19th Century. In 1809, Dom João VI, to stimulate invention in an economy primarily driven by agriculture, introduced a system of licensing, or alvará. Later in 1830, Brazil passed laws recognising the rights of inventors.

${ }_{77}$ The original Article 19 of the Berne Convention 1886 reads: "[1] Countries acceding to this Convention shall also have the right to accede thereto at any time on behalf of their colonies or foreign possessions. [2] They may for this purpose make either a general declaration of adhesion that includes all their colonies or possessions, or expressly indicate only those which are included, or which are excluded." See also Guide to the Berne Convention for the Protection of Literary and Artistic Works (Paris Act, 1971), WIPO Publication No 615 (E), ISBN 92-805-0002-3 (1978) <ftp://ftp.wipo.int/pub/library/ebooks/historicalipbooks/GuideToTheBerneConventionForTheProtectionOfLiteraryAndArtisticWorksParisAct1971.pdf $>23$ July 2014.

${ }^{78}$ Deere (n 47) 37; Okediji (n 57) 324. See also Ross (n 74) 83. As a French protectorate, Tunisia was one of the original signatories to the Paris Convention through adherence.

${ }^{79}$ RL Okediji, 'Africa and the Global Intellectual Property System: Beyond the Agency Model', Afr YB Int'l L Vol 12 Issue 1 (2004) 207-251, 216-217.

${ }^{80}$ Deere (n 47) 41. India became a member of the Paris Convention only in 1998, and Pakistan in 2004.

${ }^{81}$ Ross (n 75) 84-85. The authors point out that the general view prevailing in Latin America was that there was no benefit in joining a convention that was not flexible enough to accommodate the needs of the local economy. Also, the national-treatment principle of the Paris Convention was viewed as a barrier to the design of national regimes dealing with industrial property. They were to become signatories to the Conventions following the entry of the TRIPS Agreement. See also Deere (n 47) 41. 
nation in the most effective manner possible, while seeking to meet the ends of justice. Prior to any bill being presented before the legislature for discussion, the policy objectives are finalised, which again will be shaped by the policies of the political party in power at a given point in time. An economic analysis of any laws enacted, or is sought to be enacted, can always present an interesting insight into the political and economic policy objectives for the introduction of the law in question.

\subsubsection{Economic Theories of Intellectual Property, Traditional Views}

The foundations of economic theories are deeply entrenched in utilitarianism, and present the framework for analysis of the intellectual property rights, and in particular patent rights, as contained in the TRIPS Agreement. Utilitarian theorists have strongly supported the creation of intellectual property rights as an appropriate means to foster innovation, and in contrast non-utilitarian theorists had looked to the creator's moral rights to have control over their work. ${ }^{82}$ The legal recognition of the grant of a patent started with the passing of the Statute of Monopolies of $1623,{ }^{83}$ which also laid down the principle that only a "true and first inventor" should be granted a monopoly patent. Just over two hundred years after the passing of the Statute of Monopolies of 1623, the subject of patent reform was raised before the English Parliament, for the reason that the procedure for obtaining a patent was expensive, clumsy, and uncertain. ${ }^{84}$ This was to trigger off a debate in England, and soon to spread to the continent, where economists too would join in the debate, to create pro-patent and anti-patent lobbies. ${ }^{85}$ The lobbying and debating brought about a number of changes to the laws on patents both in England and in the Continent, besides witnessing the emergence of economic theories on the subject, with notable ones coming from England and France.

Classical writers in England almost completely fell in line with the traditional principles contained in the Statute of Monopolies of 1623 that justified the grant of temporary monopolies for the exploitation of innovations due to their special character and function, and so being exempt from the prohibition of monopoly. Jeremy Bentham, regarded as the founder of modern day utilitarianism and also a jurist, held the view that there was "one species of privilege certainly very advantageous: the patents which are granted in England for a limited time, for inventions in arts and manufactures. Of all the methods of existing and rewarding industry, this is the least burthensome, and the most exactly proportioned to the merit of the invention." $86 \mathrm{He}$ further observed, "This privilege has nothing in common with monopolies, which are justly decried." 87 Adam Smith, recognised as the pioneer of political economy, whilst referring to the risks that a company of merchants undertake and the expenses they incur to establish a new trade, held the opinion that the state should compensate the merchants by granting them "a monopoly of the trade for a certain number of years.... [to]

\footnotetext{
${ }^{82}$ PS Menell, 'Intellectual Property: General Theories' in B Bouckaert and G De Geest (eds.) Encyclopedia of Law and Economics: The History and Methodology of Law \& Economics Vol. 1 (Edward Elgar 2000) 129. $<$ http://encyclo.findlaw.com/1600book.pdf $>$ accessed 28 June 2014.

${ }^{83}$ It is widely accepted that the policy of granting privileges of monopoly under the royal prerogative in England culminated in the Statute of Monopolies of 1623. See F Machlup and E Penrose, 'The Patent Controversy in the Nineteenth Century,' The Journal of Economic History, Vol. X, No. 1 (May 1950) 1-29, 3.

${ }^{84}$ Machlup and Penrose (n 83) 3.

${ }^{85}$ Machlup and Penrose (n 83) 3. Select committees of the English Parliament and Royal commissions investigated the operation of the patent system in 1851-1852, in 1862-1865, and again in 1869-1872. Some of the testimonies before the above two commissions were so damaging to the repute of the patent system that leading statesmen in the two houses of Parliament proposed the complete abolition of patent protection. The Patent Bill 1874, although passed in the House Lords, was to be withdrawn in the House of Commons.

${ }^{86} \mathrm{~J}$ Bentham, 'Observation on Parts of the Declaration of Rights, as Proposed by Citizen Sieyes' in J Bowring (ed.), The Works of Jeremy Bentham, Vol. II (Simpkin, Marshall \& Co, London, 1843) 533.

${ }^{87}$ Ibid. See also Machlup (n 83) 7.
} 
recompense them for hazarding a dangerous and expensive experiment, of which the public is afterwards to reap the benefit. A temporary monopoly of this kind may be vindicated upon the same principles upon which a like monopoly of a new machine is granted to its inventor, and that of a new book to its author." ${ }^{88} \mathrm{He}$ also felt such monopolies for inventions could be defended on the grounds of equity, ${ }^{89}$ and as far as extending the similar rights to new books was concerned he argued that such exclusive privilege could be regarded as "an encouragement to the labours of learned men" and being beneficial to the society. ${ }^{90}$

John Stuart Mill, yet another proponent of utilitarianism, took a similar stance and categorically stated that "the condemnation of monopolies ought not to extend to patents...."91 Mill also observed that "the originator of an improved process is allowed to enjoy, for a limited period, the exclusive privilege of using his own improvement," and that inventors should be both compensated and rewarded. ${ }^{92} \mathrm{He}$ further argued that "...an exclusive privilege, of temporary duration, is preferable; because it leaves nothing to anyone's discretion; because the reward conferred by it depends upon the invention's being found useful, and the greater the usefulness, the greater the reward; and because it is paid by the very persons to whom the services is rendered, the consumers of the commodity." 93 Whereas, Michel Chevalier, the French economist was most emphatic in his opposition of both tariffs and patents, declaring that both "stem from the same doctrine and result in the same abuses." 94 The opponents of the privilege and monopoly were able to ideologically link patent protectionism with tariff protectionism and patent monopoly, to argue against monopoly privileges, which was clearly exemplified in the views expressed by Michel Chevalier. On the other hand, the advocates of a strong patent protection were able to separate the idea of patent protection from the monopoly issue and free trade issue to present the case of patent protection as one of natural law and private property, and of man's right to live by his work. ${ }^{95}$ David Hume argued that property has no purpose where there is abundance; it arises, and derives its significance, out of the scarcity of the objects that become appropriated, in a world in which people desire to benefit from their own work and sacrifice. ${ }^{96}$ Systems of Justice, he went on, protect property rights solely on account of their utility. Where the security of property is adequately assured, property owners generally see to it, that scarce 'means' are directed to those uses, which within their knowledge and judgment

\footnotetext{
${ }^{88}$ A Smith, An Inquiry Into the Nature and Causes of the Wealth of Nations - Book V, Ch. 1 Part 3 (Wordsworth Classics of World Literature, 2012) 753-754.

${ }^{89}$ Ibid. Adam Smith observed, “... if the legislature should appoint pecuniary rewards for the inventors of new machines, etc., they would hardly ever be so precisely proportional to the merit of the invention as this is. For here, if the invention be good and such as is profitable to mankind, he will probably make a fortune by it; but if it be of no value he will also reap no benefit."

${ }^{90}$ Adam Smith argued that such exclusive privileges granted to authors could be beneficial if the book be a valuable one the demand for it in that time will probably be a considerable addition to his fortune. But if it is of no value the advantage he can reap from it will be very small.' Smith (n 88).

91 JS Mill, Principles of Political Economy with Some of their Applications to Social Philosophy (Hackett Publishing 2004) Book V Chapter X, Section 4, 271-272.

92 Ibid.

${ }^{93}$ Ibid.

${ }^{94} \mathrm{M}$ Chevalier, Les brevets d'inventions dans leurs relations au principe de la liberté, du travail et de l'égalité (1878) 38. As cited in Machlup and Penrose (n 83) 9.

${ }_{95}$ Machlup and Penrose (n 83) 9. The authors, writing in 1950, observe that these arguments were still being used in the 20th century in debates on the issue.

${ }^{96}$ D Hume, Enquiries Concerning the Human Understanding and Concerning the Principles of Morals, Section III, Part II (OUP, 1902) 192-204; A Plant, 'The Economic Theory Concerning Patents for Inventions', Economica, New Series, Vol. 1, No. 1 (February 1934) 30-51. See also GE Panichas, 'Hume's Theory of Property', in K Mackinnon (ed.) Hume and Law (Ashgate, 2012) 225-239.
} 
are most productive of what they want. ${ }^{97}$ Yet another strand of thought to emerge in the 18th Century and was to play an important role in the centuries to come, was that man has a 'natural property right' in his own ideas. The French Constitutional Assembly in 1791 passed the patent laws, the preamble to which read as follows:

\begin{abstract}
...that every novel idea whose realization or development can become useful to society belongs primarily to him who conceived it, and that it would be a violation of the rights of man in their very essence if an industrial invention were not regarded as the property of its creator. ${ }^{98}$
\end{abstract}

The above preamble to a greater degree captured and encapsulated the spirit of the arguments of the pro-patent economists who favoured the grant of a patent monopoly. The Congress in US was soon to follow suit with the introduction of new patent laws in 1793, which was based on the copyright provisions contained in its Constitution. ${ }^{99}$ It is clear that the framers of the US Constitution perceived the patent system as one of incentives and rewards.

In a letter written on 13 August 1813 to the inventor Isaac McPherson, Thomas Jefferson expressed the view that, "[i]f nature has made any one thing less susceptible than all others of exclusive property, it is the action of the thinking power called an idea, which an individual may exclusively possess as long as he keeps it to himself; but the moment it is divulged, it forces itself into the possession of every one, and the receiver cannot dispossess himself of it. Its peculiar character, too, is that no one possesses the less, because every other possesses the whole of it." ${ }^{100}$ He further added that "...ideas should freely spread from one to another over the globe, for the moral and mutual instruction of man, and improvement of his condition, seems to have been peculiarly and benevolently designed by nature, when she made them, like fire, expansible over all space, without lessening their density in any point, and like the air in which we breathe, move, and have our physical being, incapable of

${ }^{97}$ Plant (n 96).

${ }^{98}$ A Schuller, 'Handbuch der Gesetze über ausschliessende Privilegien auf neue Erfindungen', Entdeckungen und Verbesserungen im Gebiete der Industrie (Vienna, 1843). As cited in Machlup (n 83) 11. One of the main arguments put forth by Stanislas de Bouffle at the time of presenting the bill to the French Constitutional Assembly in 1790 was that a man's property in his ideas was more sacred than his property in things material. See also Pierre Recht, 'Le Droit d'Auteur, Une Nouvelle Forme de Propriété: Histoire et Théorie', Paris Librarie Générale de Droit et de Jurisprudence (1969) 39. As cited in B Bouckaert, 'What is Property?' Harv J L \& Pub Pol'y (1990) 775-816, 791-792. Under this law, the right of the author to act freely with his intellectual product was linked with the generalization of the exclusivity for reproduction previously granted by the king to individual publishers. The legal protection of this exclusivity was granted to authors during their lifetimes and to their heirs for ten additional years.

99 Article I, Section 8, Clause 8 of the United States Constitution expressly vests the US Congress to create patent and copyright laws upon a utilitarian foundation, and reads as follows: 'To promote the Progress of Science and useful Arts, by securing for limited Times to Authors and Inventors the exclusive Rights to their respective Writings and Discoveries.' This clause is also referred to as the 'Copyright Clause.' Although the actual author of the copyright clause is still unknown, most commentators believe that it was either James Madison or Charles C Pinckney. See K Fenning, 'The Origin of the Patent and Copyright Clause of the Constitution,' J Pat Off Soc'y Vol. 11 (1929) 438-445, 438. See also I Donner, 'The Copyright Clause of the U.S. Constitution: Why Did the Framers Include It with Unanimous Approval,' The Am J Legal Hist Vol.36 (1992) 361-378, 361-362. Here, the author notes that at the time of the Constitutional Convention, twelve of the thirteen states had already enacted copyright laws.

100 The Letters of Thomas Jefferson 1743-1826, American History: From Revolution to Reconstruction and Beyond [A website maintained by the University of Groningen, The Netherlands] $<$ http://www.let.rug.nl/usa/presidents/thomas-jefferson/letters-of-thomas-jefferson/jefl220.php> accessed 7 August 2014; The Founders' Constitution [A website maintained by the University of Chicago, USA] $<$ http://press-pubs.uchicago.edu/founders/documents/a1_8_8s12.html> accessed 7 August 2014; See also David (n 26) 26. 
confinement or exclusive appropriation." 101 Jefferson proceeds to reject the argument of the French philosophers that inventors and authors had a 'natural rights' claim to property in their creations. He was clear in his view that inventions cannot be a subject of property in nature. ${ }^{102}$ Jefferson's comments came two decades after the passing of the first US laws on the subject in 1793, and also the fact that he was the principle author of the US Declaration of Independence and the third President of the US, cannot be ignored here.

The mainstream economics profession have consistently argued that inventors need support and protection from the government for their innovations in order to maintain an incentive for creative inquiry. The economic justification for protection of intellectual property rights is founded on the premise that unless an invention or a creation is compensated at its full social value, there will be very little incentives to undertake or engage in such activities. ${ }^{103}$ Patent rights are deliberate creations of statue law, and it is the intention of the legislators that the beneficiary shall be placed in a position to secure an income from the monopoly conferred upon him by placing restrictions on the supply of the information. ${ }^{104}$ Grant of such rights is intended to stimulate innovation by allowing the rights holder to work his patented product for a definite period of time to recover the investment, and also make a profit. Such exclusive rights are designed to empower the rights holder to prevent third parties from unauthorised use of the subject matter. So, one can assume that the statutes creating and granting patent rights monopolies would not have continued to remain in statute books, in the absence of a widespread expectation of public advantage from their operation. ${ }^{105}$ The dissenting tradition has argued that government action of any kind, including the awarding of copyrights and patents, is unnecessary to stimulate such activity. ${ }^{106}$ The picture that emerges is a debate of polarised views, with one side arguing that ideas should benefit the public and other side arguing that individuals should benefit from their ideas.

\subsubsection{Economic Analysis of Intellectual Property Laws}

As mentioned earlier, the foundations of economic theories are deeply entrenched in utilitarianism, which also provides the philosophical basis for property rights, both tangible and intangible. This section of the article seeks to analyse some of the key economic theories to emerge in the 20th century on the subject of intellectual property rights which lay the foundations for the creation of an international intellectual property rights protection regime to come in the form of the TRIPS Agreement under the auspices of the WTO. This section will also briefly study some of the views expressed in more recent times in the 21 st century. The term intellectual property has come to denote a whole set of intangible property rights which can be identified broadly under patents, copyrights, trademarks, and trade secrets. Currently, as it stands, the principal policy objective of intellectual property laws is the promotion of new and improved works through the recognition and creation of property

\footnotetext{
${ }^{101}$ David (n 26) 26. complaint from anybody." See also David (n 26) 26. in innovation or in the imitation and adaptation of others' innovations."

104 Plant (n 96).

105 Plant (n 96).

106 Plant (n 96).
}

102 Jefferson also argued, "Inventions then cannot, in nature, be a subject of property. Society may give an exclusive right to the profits arising from them, as an encouragement to men to pursue ideas which may produce utility, but this may or may not be done, according to the will and convenience of the society, without claim or

${ }^{103}$ MJ Trebilcock, R Howse, and A Eliason, The Regulation of International Trade (Routledge 2013) 515-516. The authors observe that "...in terms of neo-classical trade theory, whether a particular country will want stronger or weaker intellectual property protection will depend on whether its comparative advantage lies more 
rights, whether it is in the realms of expressive media, chemicals and pharmaceuticals, or technology, besides recognising other forms. It will, hence, be beneficial for our purposes to present a more contemporary analysis of the economic foundations of intellectual property rights and the justification for the grant of exclusive rights for inventions and other similar intangibles. The study will initially focus on intellectual property in general, and thereafter proceeding to focus on patents, more particularly on pharmaceutical patents.

There had been a fundamental shift in conventional thinking of trade as goodsoriented, which was brought about as a result of the sheer significance of intellectual property to developed economies. ${ }^{107}$ The modern day intellectual property rights principles are strongly modelled on the US intellectual property regime, which in turn is severely influenced by the pharmaceutical industry, computing industry, and music and motion picture industry. Today, much of the value of the leading corporate bodies in the world are estimated by their portfolio of intangible assets, which range from the better defined forms of intellectual property (patents and copyrights) to the least tangible of the intangibles (trade secrets, and trademarks). ${ }^{108}$ Steve Calandrillo explains the justification behind the US intellectual property regime as being built on the premise that it is socially desirable to encourage and produce many types of information, whose value to society far exceeds its developmental costs. ${ }^{109}$ Calandrillo asserts that most supporters of the US incentive system ignore the exorbitant costs it involves, and the restrictions placed upon the availability of information generated by the system. Needless to say, intellectual property rights generally confer an exclusive right to exploit the protected subject matter, or in other words, confer a right on the titleholder to prevent third parties from using the protected knowledge without authorization. ${ }^{110}$ Nonrival goods, which include knowledge, ${ }^{111}$ can be made available for public use, usually at low cost and sometimes at no cost. But knowledge can be made excludable through actions by its possessor or through legal means. ${ }^{112}$ Knowledge and

${ }^{107}$ S Marcellin, The Political Economy of Pharmaceutical Patent: US Sectional Interests and the African Group at the WTO (Ashgate, 2010) 3.

${ }_{108}$ PS Menell and S Scotchmer, 'Intellectual Property' in Handbook of Law and Economics Vol. 2, by AM Polinsky and S Shavell (eds) (Elsevier BV, 2007) 1473-1570, 1475.

109 SP Calandrillo, 'Economic Analysis of Property Rights in Information: Justifications and Problems of Exclusive Rights, Incentives to Generate Information, and the Alternative for a Government-Run Reward System,' Fordham Intell Prop Media \& Ent LJ Vol. 9 (1998) 301-360, 303.

${ }^{110}$ CM Correa, 'Managing the Provisions of Knowledge: The Design of Intellectual Property Management,' in I Kaul, et al (eds), Providing Global Public Goods: Managing Globalization (2002). The author argues that such exclusivity also impedes the diffusion and use of the knowledge so protected.

111 JE Stiglitz, 'Knowledge As A Global Public Good' in I Kaul, et al (eds) Global Public Goods: International Cooperation in the 21st Century (OUP, 1999) 308-325, 325. The author, while arguing that knowledge is a public good, expresses the view that Thomas Jefferson anticipated the modern concept of public good when he wrote to Isaac McPherson, the inventor in 1813 as follows: "he who receives an idea from me, receives instruction himself without lessening mine; as he who lights his taper at mine, receives light without darkening me."; David (n 26), where the author argues that Jefferson grasped the essential point that the cost of transmitting useful knowledge in codified form is negligible when compared with the cost of creating it, and that for society's need to encourage the pursuit of ideas, such information should be distributed freely. See MA Lemley, 'The Economics of Improvement in Intellectual Property Law,' Texas L Rev (1997) 989-1084, 995, where the author observes that public goods are "nonrivalrous" as everyone can benefit from them once they are produced. See also RS Gruner, 'Dispelling the Myth of Patents as Nonrivalrous Property: Patents as Tools for Allocating Scarce Labor and Resources,' Colum Sci \& Tech L Rev Vol. 13 (2011) 1-70. The author argues that patents are mistakenly described as nonrivalrous property, and patent rights actually govern non-rivalrous actions of parties using patented inventions, besides regulating highly rivalrous allocations of scarce resources to the production of patented inventions.

112 Correa (n 110). The author argues that a company may prevent its competitors from knowing how a particular manufacturing process operates by tightly controlling access to its physical premises and preventing the disclosure of relevant data by its employees. See also Menell and Scotchmer (108). According to the authors 
intellectual products are intangible and not appropriable, unlike tangible goods which can be appropriated and separated from the commons. ${ }^{113}$ Also, the 'consumption' of intangible goods would leave the same quantity and quality of such goods to be consumed and enjoyed by others. ${ }^{114}$

As it stands, intellectual property rights are supposed to encourage innovation. Some authors have expressed doubts as it is difficult to establish this position, and also on the other hand, intellectual property rights attempts to restrict the use of knowledge in one way or another and poses potential impediments to diffusion and cumulative innovation. ${ }^{15}$ The number of patents granted in a technologically fast growing world, especially set against the backdrop of a globalized economy, requires a different philosophical basis and a clear set of theories to justify their grant than what was presented in the 19th century US and Europe, as the rationale for grant of a monopoly has changed. ${ }^{116}$ Until the early part of the 1990 s very little empirical research was done on the impact of economics on public policy in the area of intellectual property rights, especially in comparison to the influence of professional writings in areas such as antitrust and taxation. ${ }^{117}$ In the intellectual property system, the patent right is the most powerful right, which enables the rights holder (patentee) to exclude all others from making, selling, or using the subject matter of a valid patent for a prescribed period of time. ${ }^{118}$ In practice, the patent offers the rights holder the incentive of a statutory right to exclude others from use as a means of inducing activity. ${ }^{119}$ It can be seen that the right of the patent owner is conditioned on the disclosure of the subject matter to the public when the patent is issued. ${ }^{120}$ Also, such rights allow the patentee to obtain the reward for the innovation by sale of the right conferred for a fee/royalty, or to retain the exclusive exploitation rights. ${ }^{121}$

knowledge is 'non-excludable' in its natural state, even if someone claims to own the knowledge, it is difficult to exclude others from using it. IP laws attempt to solve this problem by legal means, by granting exclusive use of the protected knowledge or creative work to the creator. Through the device of intellectual property the inventor can control entry and exclude users from the intangible assets. See also NS Kinsella, 'Against Intellectual Property,' Journal of Libertarian Studies Vol. 15 No. 2 (2001) 1-53. The author strongly argues that in today's world, the institution of intellectual property rights deliberately creates scarcity when none existed before, so as to enable the commodification and appropriation of otherwise plentiful, non- rivalrous intellectual goods.

${ }^{113}$ V Muzaka, The Politics of Intellectual Property Rights and Access to Medicines (Palgrave Macmillan, 2011) 18.

114 J Hughes, 'The Philosophy of Intellectual Property,' Geo LJ Vol.77 (1988) 287-366. The author also observes that much of the IP generated "....is produced only after considerable financial investment, whether it be in the research laboratory or in the graduate education of the scientist using the facility." And that "[o]ne cannot call the history of intellectual property a purely proletarian struggle."

115 JE Stiglitz, 'Economic Foundations of Intellectual Property Rights', Duke LJ (2008) 1693-1724, 1696; Menell and Scotchmer (n 108) 1476.

${ }^{116}$ For instance, significant changes have taken place in the legal approach to the grant of patents to software since the late 1970s. When VisiCalc, the first computer spreadsheet program, was developed in 1979, the US Patent Office, relying upon US Supreme Court case law, took the position that the mathematical algorithms in computer programs were incapable of being protected as a subject matter. This position was, of course, to change when the US Supreme Court in the Diamond $v$ Diehr case [450 U.S. 175, 185-187 (1981)] held that controlling the execution of a physical process, by running a computer programme did not preclude patentability of the invention as a whole, and found patentable subject matter in a process utilizing a computer algorithm.

${ }^{117}$ SM Besen and LJ Raskind, 'An Introduction to the Law and Economics of Intellectual Property,' The Journal of Economic Perspectives, Vol. 5, No. 1 (1991) 3-27, 4.

${ }^{118} \mathrm{Ibid}, 7$. The patentee can even prevent an independent subsequent discoverer of the same subject matter from making, using or selling it.

${ }^{119}$ Besen and Raskind (n 117) 8.

${ }^{120}$ Besen and Raskind (n 117) 8.

${ }^{121}$ ML Katz and C Shapiro, 'On the Licensing of Innovations,' The RAND Journal of Economics, Vol. 16, No. 4 (1985) 504-520. The authors argue that major innovations are not normally licensed, but equally efficient 
Currently, under the TRIPS Agreement the term of the patent granted is for a period of 20 years, but some pharmaceutical patent holders are known to extend this term beyond the said period. ${ }^{122}$

Guido Calabresi and Ronald Coase in the 1960s were the first to attempt and apply economic analysis in a systematic way to areas of law that did not purport to regulate economic relationships. ${ }^{123}$ Edmund Kitch, a legal scholar and economist, is of the opinion that although good progress was made in the understanding of economics of intellectual property rights in the 20th century, much still remains to be done. ${ }^{124} \mathrm{Kitch}$, in his article, identifies recurring errors in the literature on the subject matter and proceeds to analyse them individually. $\mathrm{He}$ is of the strong view that writers over a period of time have repeatedly analysed intellectual property rights on the assumption that they confer an economic monopoly on the rights holder. ${ }^{125}$ Kitch observes that most authors begin with an analysis of intellectual property rights on the presumption that the rights holder of the intellectual property possesses an economic monopoly, namely, a monopoly where the rights holder is protected from competition and is also able to sell into a market with a downward sloping demand curve. ${ }^{126} \mathrm{He}$ further argues that characterization of patents as a monopoly can only be true if the claims cover all of an economically relevant market, i.e., there is no alternative way for competitors to provide the same economic functionality to their customers without infringing the claims. The error that Kitch identifies in the analysis carried out by most writers on the subject is the use of the basic diagram/graph to study the competitive market where the parameters are not clearly identified, and hence "the market reflected in the diagram is not the market for the intellectual property right itself." ${ }^{127}$ For Kitch, the empirical question if intellectual property rights confer any economic monopoly, although persistently raised in the literature; is not properly addressed, as it is addressed only in passing. ${ }^{128}$

firms will tend to license minor innovations, and also for some innovations, licensing is both privately and socially undesirable.

122 Patent holding transnational pharmaceutical corporations are known to extend the period of patent through the practice of evergreening, which is also referred to as, 'patent-layering' and 'life-cycle management.' This practice effectively blocks the entry of generics into the market. See LJ Glasgow, 'Stretching the Limits of Intellectual Property Rights: Has the Pharmaceutical Industry Gone Too Far?' (2001) 41 IDEA 227. India, a developing country introduced provisions through its TRIPS compliant patent legislation to check the practice. See Sundaram (n 39) 20-26.

${ }^{123}$ G Calabresi, 'Some Thoughts on Risk Distribution and the Law of Torts,' Yale LJ (1961) 499-553; R Coase, 'The Problem of Social Cost,' 3 JL \& Econ Vol. 3 (1960) 1. Both, Calabresi and Coase are seen as pioneers in the field of new economic analysis of law. See RA Posner, 'The Economic Approach to Law', Tex L Rev (1975) 757-782 759-60.

${ }^{124}$ EW Kitch, 'Elementary and Persistent Errors in the Economic Analysis of Intellectual Property,' Vand L Rev Vol. 53 (2000) 1727-1741, 1728.

125 Ibid, 1729.

${ }^{126}$ Ibid 1729-30. Kitch argues that a clear distinction is to be made "...between the issue of whether intellectual property rights confer an economic monopoly, and thus impose the social welfare cost associated with monopoly, and the fact that intellectual property rights systems have costs - as does any system of property rights."

${ }^{127}$ Ibid 1734. Kitch also opines that all systems of property rights do involve costs to define the scope of their rights, in detecting and preventing trespass, and also "in foreclosing particular productive opportunities that might be possible if the property system did not exist. Any system of property rights is appropriately subject to examination as to whether the benefits of the property system outweigh these costs, but that examination has nothing to do with the social welfare loss caused by economic monopolies."

128 See Lemley (n 111) 996. The author makes an interesting observation that while some intellectual property rights "may in fact give their owner power in an economically relevant product market, most do not; they merely prevent others from competing to sell copies of a particular product, not from selling different products that compete with the original." 
Kitch also notes that much of the analysis of intellectual property rights proceeds on the footing that an author or inventor creates a work or an invention, who then wishes to exploit it commercially. This analysis, according to Kitch, conveniently leaves out of the equitation the interaction between intellectual property rights on any one work or invention and the creation of other works and inventions - in other words it forgets, or ignores the fact that authors make use of existing cultural elements; likewise, inventors build on the work of inventors who preceded them. ${ }^{129}$ Suzzane Scotchmer presents a similar, and more emphatic argument on the point, by stating that most innovators "stand on the shoulders of giants, and never more so than in the current evolution of high technologies, where almost all technical progress builds on a foundation provided by earlier innovators." 130 Scotchmer presents instances in support of her argument, from molecular biology, pharmaceuticals, computers and cotton gin. Scotchmer's primary argument is that later day innovators simply bettered previous technologies. She also observes that most economic literature on patenting has proceeded to "study innovations in isolation, without focusing on the externalities or spillovers that early innovators confer on later innovators. But the cumulative nature of research poses problems for the optimal design of patent law that are not addressed by that perspective." 131 Based on the above, one is tempted to conclude, instantly, that it is mere cumulative research leading to innovation, which in the eye of the law is patentable and hence resulting in the 'inventor' being rewarded with exclusive patent rights.

Joseph Stiglitz, a Nobel Laureate in economics, observes that many of the most important ideas like the mathematics that underlies the modern computer, the fundamentals behind atomic energy, lasers, etc., are not protected by intellectual property rights, and have been used freely by academics and researchers, and also that academics disseminate their research findings without charging for them. He is also of the strong opinion that products of immediate commercial value can be produced without IP protection. Stiglitz argues that, in contrast, an IP regime rewards innovators by creating a temporary monopoly power, which allows the rights holder to charge far higher prices than they could possibly charge if there were to be a competition. He is of the further view that in the above process, ideas are used and disseminated far lesser than they would be otherwise. ${ }^{132}$ For Stiglitz, once a monopoly is established under an intellectual property regime it may be hard to dislodge, as a monopoly can use its market power to crush competitors, and cites Microsoft as a classic example. Fritz Machlup, in a study carried out on the US patent system for the Subcommittee on Patents, Trademarks, and Copyrights, observes that there is a general perception that 'property' and 'monopoly' are one and the same from an economic perspective, and the rights holder of an invention has a 'monopoly' over its use just as the owner of a house has a 'monopoly' of the use of the house, which according to Machlup could encumber economic analysis. ${ }^{133}$ In his view, 'property' and 'monopoly' has almost nothing to do with each other, for a seller

129 Kitch (n 124) 1738-1739.

${ }^{130}$ S Scotchmer, 'Standing on the Shoulders of Giants: Cumulative Research and the Patent Law,' The Journal of Economic Perspectives, Vol. 5, No 1 (1991) 29-41, 29-30. To drive home the point, Scotchmer also quotes Sir Isaac Newton, who famously said, "If I have seen far, it is by standing on the shoulders of giants."

131 Ibid.

132 JE Stiglitz, 'Intellectual-Property Rights and Wrongs,' Daily Times (5 August 2005) <https://www.projectsyndicate.org/commentary/intellectual-property-rights-and-wrongs> accessed 29 July 2014.

133 F Machlup, 'An Economic Review of the Patent System', Study of the Subcommittee on Patents, Trademarks, and Copyrights of the Committee on the Judiciary, United States, Senate, Eighty-Fifth Congress, Second Session; Pursuant to S. Res. 236 (US Government Printing Office, 1958) 53. The author also observes that there is some confusion regarding the meaning and object of 'property' and 'property rights', which again is more troublesome to lawyers than economists, and how quite often the controversial idea of property right in an invention is confused with the non-controversial idea of a property right in a patent. 
owning his wares will have property but not monopoly - if others sell similar things in the same market. Likewise, for a seller who controls the price of what he sells in a certain market, as there is no serious competition, may have a monopoly but not property - if he does not own what he sells. ${ }^{134}$ What one need to be mindful of is that the term property, although used frequently in discussions, is indeed complex and highly political besides being in every way legal, as it vests the individual with tangible and intangible rights.

For Landes and Posner, the standard rationale of patent law is that "it is an efficient method of enabling the benefits of research and development to be internalized, thus promoting innovation and technological progress." 135 According to Landes and Posner the rationale for granting legal protection to inventions is the difficulty that a manufacture may encounter whilst trying to recover his fixed costs of research and development when the product or process that embodies a new invention is readily 'copiable'. But this protection presents a greater danger, as the "inventor will be enabled to charge a higher price than he needs to recover for the fixed costs of his invention, thereby restricting access to the invention more than is necessary." 136 Landes and Posner also argue that the greater the patent protection afforded, the smaller the benefit to competitors, as there will be very little information available to them and any costs of working around the patent will be higher. ${ }^{137}$ They also assert that a patentee's monopoly mark-up, which is influenced by the degree of protection afforded, bears no direct relation to the fixed costs that the patentee incurred in the creation of the patented product. Landes and Posner also maintain that legislation and policy are for the most part non-excludable public goods, ${ }^{138}$ and in contrast intellectual property is an excludable public good. While this is the case, the public-choice theory, seen as the driving force behind policy decisions, had neither succeeded in explaining the forces that brought into being the system of property rights that is fundamental to a capitalist economy, nor had it said anything about the extension of that system to encompass intellectual property. ${ }^{139}$

Richard Posner, in a more recent contribution made to an on-line blog, expresses concerns that both patent and copyright protection, particularly the former, may be excessive. He argues that the cost of inventing must be comparable to the cost of copying in order to determine the optimal patent protection for an inventor, and that when patent protection is too strongly in favour of the inventor, market efficiency is decreased. ${ }^{140}$ Posner also avers that pharmaceutical drugs are the 'poster child' for patent protection, and that "few other products have the characteristics that make patent protection indispensable to the pharmaceutical industry." 141 The most interesting, if not scathing, comment to come from Posner is with regards to the 20-year duration of the patent protection, which he feels confers no real benefit - except to enable the producer to extract license fees from firms wanting to make a different product that incorporates his invention. Posner concludes the brief with a parting shot that the

134 Ibid, 54.

${ }^{135}$ WM Landes and R Posner, The Economic Structure of Intellectual Property Law (Harvard University Press, 2003) 294.

${ }^{136}$ Ibid, 296. The authors also argue that this fear may explain the reason for the term of a patent being shorter, than the term of a copyright.

${ }^{137}$ Ibid 299.

${ }^{138}$ Ibid 403. The authors observe that "A person can enjoy the full benefit of the statute, regulation, or other policy in question without having contributed a dime to the collective effort that was necessary to get it promulgated."

139 Ibid 403-404.

${ }^{140}$ R Posner, 'Do Patent and Copyright Law Restrict Competition and Creativity Excessively?' The BeckerPosner Blog (30 September 2012) <http://www.becker-posner-blog.com/2012/09/do-patent-and-copyright-lawrestrict-competition-and-creativity-excessively-posner.html $>$ accessed 12 August 2014.

${ }^{141}$ Ibid. 
need for reform of both patent and copyright laws are sufficiently acute to warrant a serious attention from the US Congress and the courts. ${ }^{142}$ In his view, the long protection given to patents under the current US laws, leads to profiteering by the rights holder, which defeats the very basis for the grant of a patent protection. This strong criticism can be extended to the 20 year patent protection granted under the TRIPS Agreement, which was in turn shaped by the US led developed countries during the Uruguay Round of negotiations.

From the above discussions what one can infer is that economic theories have not yet succeeded in producing a convincing and coherent set of principles to justify intellectual property protection for intangible rights. This argument can be extended to its global applications too, as the American intellectual property protection policy narrative has been embraced by developed nations and applied globally through the WTO. What we witness now is the evolution of intellectual property laws following the school of thought based on 'wealth maximization,' ${ }^{143}$ and the establishment of an international regime which provides strong intellectual property rights protection for innovations, which are held and exploited by patent holding developed nations, to the detriment of non-owners. This approach to intellectual property rights protection goes even beyond the utilitarian principles expounded by Jeremy Bentham, as it completely disregards other human values, including the needs of the society. While making the above criticism one cannot ignore the fact that we live in an information-driven society, where developed economies are strong information producers, and naturally expected to support the establishment of strong intellectual property rights laws to serve their interests. In the above landscape intellectual property rights policies emerge as essential organizational principles of the knowledge based economy, since it determines the way in which knowledge relations are structured and governed. ${ }^{144}$ The modern, or contemporary, perception of intellectual property rights is strongly influenced and shaped by US expansionist economic policies and law making. It has its foundations in utilitarianism, Lockean model of natural laws, besides being strongly influenced by the common law notions of property rights. This understanding of intellectual property, as propagated by Anglo-Saxon jurisprudence, and later by Anglo-American jurisprudence (which in turn is influenced by Posnerian economic analysis from the 1970s), has paved the way for a winnertake-all 'wealth maximization' approach. One should note that the US and its allies (developed countries with a similar vision) have a strong knowledge based economy, and can afford to promote an intellectual property rights regime which gives the rights holder an extended term of monopoly over information/knowledge, which makes any intellectual property product relying on such information scarce and unaffordable in the developing world. This approach to intellectual property, most notably, has a significant impact on the pharmaceutical products and affects access to medicines in developing countries and LDCs.

\subsubsection{Human Rights Analysis of Intellectual Property Rights \& the TRIPS Agreement}

One key area of study that is constantly overlooked while discussing the importance of intellectual property policy and legislation is the human rights aspect for the grant of intellectual property rights. This lacuna in the debate on the justification for grant of property rights for intangibles, has particularly gained in significance in the case of pharmaceutical patents, as access to medicines have become a major issue since the entry into force of the TRIPS Agreement. As a result, there is an inadequate understanding of the complex

\footnotetext{
142 Ibid. See also R Posner, The Economics of Justice (Harvard University Press 1983) 75-115, where Posner advocates and argues for 'wealth maximization' as the guiding principle of common law.

${ }^{143}$ Posner (n 142). 75. Posner argues that the "basic function of law in an economic or wealth-maximization perspective is to alter incentives."

${ }^{144}$ R Ghafele, 'Perceptions of Intellectual Property: A Review' University Library of Munich, Germany, (2008).
} 
justification of intellectual property rights policy, legislation, Conventions, and most importantly the TRIPS Agreement, which while extending the period of patents on pharmaceutical and other patents to 20 years, has effectively outlawed process patents of pharmaceuticals. The Universal Declaration of Human Rights 1948 (UDHR) provides that "everyone has the right to the protection of the moral and material interests resulting from any scientific, literary or artistic production of which he [or she] is the author." 145 Similarly, the creators' rights are also identified and recognized in the International Covenant on Economic, Social and Cultural Rights (ICESCR). ${ }^{146}$ Some writers have speculated that the protection of creators' rights found in the above international instruments was no accident. ${ }^{147}$ These solemn assertions are to be found in the international conventions passed post-World War II. Similarly, commitment to the guarantee of the right to good health is to be found in most national constitutions. These guarantees, or undertakings, made at the highest levels of governance has now been jeopardised by the development of international instruments, both through WTO under multilateral trade agreements, and other plurilateral agreements negotiated by developed nations and their trading partners. It will not be out of place to point out that there is no reference to human rights appearing in the Paris Convention, ${ }^{148}$ Berne Convention, ${ }^{149}$ the Rome Conventions, ${ }^{150}$ and in the more recently adopted TRIPS Agreement. Importantly, the TRIPS Agreement requires all Member States to comply with pre-existing international agreements on intellectual property laws including the Paris Convention and Berne Convention. But all the above treaties do refer to the protections granted to authors and inventors as 'rights.' Helfer and Austin argue that the principal justification for such rights lies not in deontological claims about the inalienable liberties of human beings, but rather in the economic and instrumental benefits that flow from the protection of intellectual property across national borders. ${ }^{151}$

Intellectual property rights protection is alluded to in the human rights protection found in the cultural rights of Article 25 of the UDHR and Article 15 of the ICESR. Principles of human rights demand that all individuals are granted, or, are presumed to have the right to good health. Article 25(1) of the UDHR provides that everyone "has the right to a standard of living adequate for the health and well-being of himself and of his family,

${ }^{145}$ Universal Declaration of Human Rights 1948. The declaration arose directly from the experience of the II World War, and is viewed as a milestone in the history of human rights. See P Torremans (ed.), Copyright and Human Rights: Freedom of Expression, Intellectual Property, Privacy (Kluwer Law International 2004) 5. See also LR Helfer and GW Austin, Human Rights and Intellectual Property: Mapping the Global Interface (Cambridge University Press, 2011) 32. The author notes that UDHR "was drafted less than three years after the end of the II World War and science and technology as well as copyright based propaganda had been abused for atrocious purposes by those who lost the war. Such an abuse had to be prevented for the future and it was felt that the best way forward was to recognize that everyone had a share in the benefits and that at the same time those who made valuable contributions were entitled to protection."

${ }^{146}$ International Covenant on Economic, Social and Cultural Rights 1966. Entered into force on 3 January 1976, and as of July 2014 has been ratified by 162 countries.

147 One of the legal scholars, commenting on the inclusion of Article 27 in the UDHR, observes as follows: "What we know is that the initial strong criticism that intellectual property was not properly speaking a Human Right or that is already attracted sufficient protection under the regime of protection afforded to property rights in general was eventually defeated by a coalition of those who primarily voted in favour because they felt that the moral rights deserved and needed protection and met the Human Rights standard and those who felt the ongoing internationalization of copyright needed a boost and that this could be a tool in this respect." Torremans (n 145) 6. See also Helfer and Austin (n 145).

148 Paris Convention (n 72).

${ }^{149}$ Berne Convention (n 73).

150 International Convention for the Protection of Performers, Producers of Phonograms and Broadcasting Organizations 1961 (adopted at Rome, Italy on 26 October 26 1961). Also referred to as The Rome Convention.

${ }^{151}$ Helfer and Austin (n 145) 32-33. 
including food, clothing, housing and medical care and necessary social services, and the right to security in the event of unemployment, sickness, disability, widowhood, old age or other lack of livelihood in circumstances beyond his control." ${ }^{152}$ Likewise, Article 15.1(c) of the ICESCR recognises the right of the creator to "benefit from the protection of the moral and material interests resulting from any scientific, literary or artistic production of which he is the author", and such expression entitles "both individuals or groups or communities to a right to intellectual property protection for his own creation." ${ }^{153}$ Similar expressions are to be found in Article 27 of the UDHR regarding the individual's right to "the protection of the moral and material interest resulting from any scientific, literary or artistic production of which he is the author." 154 What is glaringly missing here is the exact scope of the right to "scientific, literary or artistic production," as it is unclear if it includes inventors and patent protection. ${ }^{155}$ When examining the implications of intellectual property rights over human rights, policy makers, inter-governmental and non-governmental organizations, international bureaucrats, and scholars usually employ the conflict approach or the coexistence approach. ${ }^{156}$ The first mentioned conflict approach views the two sets of rights as being in fundamental conflict and the coexistence approach considers them as essentially compatible. ${ }^{157}$ Professor Peter $\mathrm{Yu}$ notes that while the two approaches may have its own benefits and drawbacks, both ignore, or overlook the fact that "some attributes of intellectual property rights are protected in international or regional human rights instruments while other attributes do not have any human rights basis at all." ${ }^{158}$ Interestingly, UN Sub-Commission on the Promotion and Protection of Human Rights, and the WTO has adopted the conflict approach and the coexistence approach respectively. Professor Yu presents a third approach and argues that "instead of inquiring whether human rights and intellectual property rights conflict or coexist with each other, it is important to identify the human attributes of intellectual property rights and distinguish them from the non-human rights aspects of intellectual property protection." 159

The existing tensions between intellectual property rights and human rights was summarised by the United Nations Committee on Economics, Social and Cultural Rights in

152 Article 25 (1), Universal Declaration of Human Rights 1948. See also P Xiong, An International Law Perspective on the Protection of Human Rights in the TRIPS Agreement (Martinus Nijhoff Publishers, 2012) 57. 153 A Chapman, 'Approaching Intellectual Property as a Human Right: Obligations Related to Art 15.1(c)' UNESCO Publishing Vol. XXXV, No. 3 (2001) 6. Here, the author expresses a strong view that the inventor can be a group or a community as well as an individual, which is in contrast with the individualism of intellectual property. See also Xiong (n 152).

154 Article 27, Universal Declaration of Human Rights 1948.

155 See also Xiong (n 152) 58.

156 Torremans (n 145). See also LR Helfer, 'Human Rights and Intellectual Property: Conflict or Coexistence? Minn. Intell. Prop. Rev. Vol. 5, Issue 1 (2003) 47-61. The author argues that allowing greater opportunities for airing human rights perspective on IP issues will strengthen the legitimacy of the WTO and the WIPO.

${ }^{157}$ For example, the UN Sub-Commission on the Promotion and Protection of Human Rights has adopted the 'conflict approach,' noting that "actual or potential conflicts exist between the implementation of the TRIPS Agreement and the realization of economic, social and cultural rights..." See UN Commission on Human Rights, Sub-Commission on the Promotion and Protection of Human Rights, 'Intellectual Property Rights and Human Rights', Resolution 2000/7, Preamble, Recital 1 (17 August 2000) [Document E/CN.4/Sub.2/2000/2000/7]. In contrast the WTO has adopted the 'coexistence' approach, emphasising the availability of built-in flexibilities in existing international trade agreements. See World Trade Organization Protection of Intellectual Property Under the TRIPS Agreement (27 November 2000) [UN.Doc.E/C.12/2000/18].

${ }^{158}$ PK Yu, 'Ten Common Question About Intellectual Property and Human Rights,' Ga St UL Rev 23 (2006) 709-753,709-10. See also PK Yu, 'Reconceptualizing Intellectual Property Interests in a Human Rights Framework,' UC Davis L Rev Vol. 40 (2007) 1039.

${ }^{159} \mathrm{Yu}(\mathrm{n} 158)$ 710-11. 
2001 as follows: "The allocation of rights over intellectual property has significant economic, social and cultural consequences that can affect the enjoyment of human rights". ${ }^{160}$ These tensions are obviously driven by the manner in which creative works, cultural heritage and scientific knowledge are turned into property at an alarming pace, which has significant human rights implications. ${ }^{161}$ Audrey Chapman expresses the strong view that intellectual property rights should be viewed as human rights, as the three provisions of Article 15.1(c) of the ICESCR were viewed by drafters as intrinsically interrelated to one another, that the rights of authors and creators were understood as essential preconditions for cultural freedom and participation and scientific progress and not as good in themselves. ${ }^{162}$ Chapman also argues that in order to be consistent with the provisions of Article 15, intellectual property laws must assure that intellectual property protections complement, fully respect, and promote other components of Article 15. This caveat is served so that the rights of authors and creators facilitate rather than constrain cultural participation on the one side and scientific progress and access on the other. ${ }^{163}$ For Chapman, under the human rights approach, an author, artist, or creator can be a group or a community as well as an individual. This approach strikes a balance between the rights of inyentors and creators and the interests of the wider society within intellectual property paradigms and it makes it far more explicit and exacting, which means the rights of the creator are not absolute but conditional on contributing to the common good and welfare of society. ${ }^{164}$ There is yet another argument that some aspects of intellectual property rights have potentially adverse implications for human rights, ${ }^{165}$ which finds support in the observations made in the study carried out by the High Commission on Human Rights on the impact of TRIPS Agreement on human rights. This study acknowledges that Article 15 of the ICESCR clearly identifies the need to balance the protection of both public and private interests. ${ }^{166}$

The UNHCR Committee on Economic, Social and Cultural Rights adopted General Comment 17, which elaborates on the right of everyone to benefit from the protection of the moral and material interests resulting from any scientific, literary or artistic production of which he is the author, as set out in Article 15.1(c), of the Covenant. ${ }^{167}$ It is noted in General Comment 17 that human rights are fundamental and inalienable, and are universal entitlements belonging to individuals and, under certain circumstances, groups of individuals and communities. It further elaborates that human rights are fundamental as being inherent to

160 Statement by the United Nations Committee on Economic and Cultural Rights (UNCECR), Substantive Issues Arising in the Implementation of the International Covenant on Economic, Social and Cultural Rights Follow-up session to the day of general discussion on article 15.1(c), Monday 26 November 2001, Human Rights and Intellectual Property. United Nations Committee on Economic, Social and Cultural Rights, 14 December 2001, para 1 [Document E/C.12/2001/15].

161 D Matthews, 'Intellectual Property Rights, Human Rights and the Right to Health' in FW Grosheide (ed.), Intellectual Property and Human Rights: A Paradox (Edward Elgar, 2010) 118-39, 118.

162 Chapman (n 153) para 23.

163 Chapman (n 153) para 24.

164 Chapman (n 156) para 26-27. The author also argues that "[u]nless human rights advocates provide an effective intellectual and organizational counterweight to economic interests, the intellectual property landscape will be reshaped in the years ahead without adequate consideration of the impact on human rights."

165 Matthews (n 161) 122.

${ }^{166}$ United Nations Commission on Human Rights (2001), 'Economic, Social and Cultural Rights: The impact of the Agreement on Trade-Related Aspects of Intellectual Property Rights on human Rights. Report of the High Commissioner,' 27 June 2001, E/CN.4/Sub.2/2001/13, page 5.

167 General Comment No. 17: The right of everyone to benefit from the protection of the moral and material interests resulting from any scientific, literary or artistic production of which he is the author (Article 15(1)(c) of the Covenant), adopted by the UNHCR Committee on Economic, Social and Cultural Rights on 21 November 2005 (E/C.12/2005/GC/17). Available in 'Human Rights Instruments, Vol I, Compilation of General Comments and General Recommendations Adopted by Human Rights Treaty Bodies’ HRI/GEN/1/Rev.9 (Vol I) 123- 138. 
the human person as such, whereas intellectual property rights are means through which States seek to provide incentives for inventiveness and creativity, encourage the dissemination of creative and innovative productions, as well as the development of cultural identities, and preserve the integrity of scientific, literary and artistic productions for the benefit of society as a whole. ${ }^{168}$ The most interesting comments come in paragraph 2 of the General Comments, where it is stated that human rights are timeless expressions of fundamental entitlements of the human person, whereas intellectual property rights are of a temporary nature, and can be revoked, licensed or assigned to third parties, and can also be allocated, limited in time and scope, traded, amended and even forfeited. ${ }^{169}$ Besides, the scope of protection of the moral and material interests of an author provided for by Article 15.1(c), does not necessarily coincide with what is referred to as intellectual property rights under national legislations or international instruments, and hence, it is important that intellectual property rights are not sought to be balanced with the human right recognized in Article 15.1(c). ${ }^{170} \mathrm{~A}$ bare reading of the above international instruments causes confusion, as intellectual property rights are identified as human rights, which has a far wider scope to achieve than the narrow private proprietorial right envisaged under intellectual property rights. This has undermined the position of the advocates of human rights who see intellectual property rights being given preference over their right to good health and life in the debate on access to affordable medicines. While the above debate rages on; the expanded intellectual property rights protection imposed through the WTO had caused unnecessary hardship and suffering in the developing countries and LDCs due to scarcity of access to affordable medicines. What is obvious from the above discussion is that the relationship between intellectual property rights and human rights remains unclear ${ }^{171}$ to the greatest disadvantage of the real sufferers from the exploitation of intellectual property rights by transnational corporations.

Most Member States of the WTO who have undertaken to implement the minimum standards of intellectual property protection in the TRIPS Agreement have also ratified the ICESR, which means the Member States have a double duty to implement the minimum standards of the Agreement bearing in mind their human rights obligation. ${ }^{172}$ The question that we ask is should the Member States interpret the Agreement as only safeguarding trade interests, or should it be read in light of the importance of upholding the needs and interests of all market actors, including corporations and individual human beings? ${ }^{173}$ Importantly, do all international instruments, including the specialist TRIPS Agreement strike a right balance between human rights and intellectual property rights? Sadly, the literature available on the point seems to indicate that they do not strike a balance, and one can assume that intellectual property rights have a more favoured position than human rights in the debate. Finding a link between the standards of TRIPS and human rights is not the same as saying that TRIPS takes a human rights approach to intellectual property protection; the primary question is whether TRIPS strikes a balance that is consistent with a human rights approach. ${ }^{174}$ The Resolution

\footnotetext{
${ }^{168}$ General Comment 17 (no 163) para 1.

169 General Comment 17 (no 163) para 2.

${ }^{170}$ General Comment 17 (no 163) para 2-3.

${ }^{171}$ Helfer (n 156). See also generally Helfer and Austin (n 145).

${ }^{172}$ G Dutfield and U Suthersanan, Global Intellectual Property (Edward Elgar, 2008) 224-225.

173 Ibid.

${ }^{174}$ See Report of the UN High Commissioner for Human Rights, The Impact of the Agreement on Trade-Related Aspects of Intellectual Property Rights on Human Rights, E/CN.4/Sub.2/2001/13, pp. 7-11. See also J Mwangi, 'TRIPS and Agricultural Biotechnology: Implications for the Right to Food in Africa,' in M Sinjela (ed.) Human Rights and Intellectual Property Rights: Tensions and Convergences (Martinus Nijhoff Publishers, 2007) 265.
} 
2000/7 of the UN Commission on Human Rights on IP and human rights goes as far as to state that the WTO is "a veritable nightmare" for certain sectors of humanity, ${ }^{175}$ in that the TRIPS Agreement in some ways encourages, or has as a side-effect human rights violations. ${ }^{176}$ The report concludes thus:

"Since the implementation of the TRIPS Agreement does not adequately reflect the fundamental nature and indivisibility of all human rights, including the right of everyone to enjoy the benefits of scientific progress and its applications, the right to health, the right to food and the right to self- determination, there are apparent conflicts between the intellectual property rights embodied in the TRIPS Agreement, on the one hand, and international human rights law on the other".

The above Resolution of the Sub-Commission on Human Rights also identifies the areas of actual or potential conflict between human rights and intellectual property rights as, impediments resulting from the application of intellectual property rights to the transfer of technology to developing countries; the consequences of plant variety rights and the patenting of genetically modified organisms for the enjoyment of the basic right to food; the reduction of control by communities (especially indigenous communities) over their own genetic and natural resources and cultural values, leading to accusations of 'biopiracy'; restrictions on access to patented pharmaceuticals and the implications for the enjoyment of a basic right to health. ${ }^{177}$ The Resolution goes further to affirm the right to protection of the moral and material interests resulting from any scientific, literary or artistic production of which one is the author as a human right, which is however subject to limitations in the public interest. A year later in 2001, Resolution 2001/21, ${ }^{178}$ was adopted wherein it was noted that the implementation of TRIPS did not adequately reflect the fundamental nature and indivisibility of all human rights, including the right of everyone to enjoy the benefits of scientific progress and its applications, and that there are apparent conflicts between the intellectual property rights regime embodied in TRIPS, on the one hand, and international human rights law, on the other. The resolution also recommended that an assessment be made to study if the patent 'as a legal instrument' was compatible with the promotion and protection of human rights; and the impact of the TRIPS Agreement on the rights of indigenous peoples. It is relevant to point out here that both Resolutions, 2000/7 and 2001/21, of the Sub-Commission observe that human rights prevailed over all economic rights and should be taken into account in the drafting of economic rights policies. ${ }^{179}$ Sadly, not much progress has been made since the making of the above two resolutions.

It is abundantly clear that there exists an apparent conflict between the 'private' interests of intellectual property rights holders, which is contained in the TRIPS Agreement,

\footnotetext{
${ }^{175}$ UN Commission on Human Rights, Sub-Commission on the Promotion and Protection of Human Rights, 'Intellectual Property Rights and Human Rights', Resolution 2000/7, 17 August 2000, para 1 [Document E/CN.4/Sub.2/2000/2000/7].

${ }^{176}$ F Papadopoulou, 'TRIPS and Human Rights', in A Kur (eds.) Intellectual Property Rights in a Fair Trade System: Proposals for Reform of TRIPS (Edward Elgar, 2011) 262.

177 UN Commission on Human Rights, Sub-Commission on the Promotion and Protection of Human Rights, Resolution 2000/7 (n171).

${ }^{178}$ UN Commission on Human Rights, Sub-commission on the Promotion and Protection of Human Rights, 'Intellectual Property Rights and Human Rights', Resolution 2001/21, 16 August 2001 [Document E/CN.4/Sub.2/Res/2001/21].

${ }^{179}$ UN, Sub- Commission Resolution 2000/7 at point 2 and Sub- Commission Resolution 2001/21 at point 7.
} 
and the 'social' or 'public' concerns found in international human rights law. ${ }^{180}$ The TRIPS Agreement has successfully tilted the balance inherent in intellectual property law away from the public interest and in favour of intellectual property rights holders. ${ }^{181}$ One of the major shortcomings of the TRIPS Agreement is that it does not have the promotion and protection of human rights at the heart of the aim of intellectual property protection, but rather more as an exception. The promotion of health, nutrition, etc., which are links to human rights, are all generally expressed in terms of exceptions to the rule. ${ }^{182}$ Further, TRIPS Agreement only recognises individual rights by clearly stating in the preamble that intellectual property rights are private rights, which ignores the creativity and innovation of groups and communities. ${ }^{183}$ This position undoubtedly weakens the objectives on human rights contained in the Agreement. As observed by Dutfield and Suthersanan, the resolutions and reports produced by the UN Commission on Human Rights in the area of intellectual property rights have been unanimous in their view that there was a need for law makers to take international human rights into account in international economic policy formulation, and emphasised the primacy of the former over the latter. ${ }^{184}$ The authors also point out that none of the resolutions and reports suggest that intellectual property rights per se conflict with human rights, but rather that the problems lie in the implementation of the TRIPS Agreement, and that the implication is that there must be a concerted attempt to interpret TRIPS as if human rights norms and considerations were part of the drafting process. ${ }^{185}$

The right to health as found in international instruments, due to its indeterminacy and vagueness, makes it appear more aspirational rather than justiciable and hence difficult to implement at the national level, ${ }^{186}$ and it is hence important to clarify the position of the right to health and its remit in international instruments. UDHR and other international instruments view intellectual property rights as part and parcel of human rights, or in other words intellectual property rights are seen as being contained in human rights. This position only favours those seeking a much stronger and wider intellectual property rights protection, which effectively side-lines all other social and public concerns at the heart of the human rights argument. As Michael Santoro points out, negative rights require the duty holder to "...forbear from interfering with the right holder" but whereas positive rights like the right to health care will require someone to act for, or provide something to the right holder. ${ }^{187}$ This, according to Santoro "raises the question of who exactly has a duty to honour the human right to drugs." 188 The problem clearly appears to be the mistake of trying to balance out private rights (negative rights) with the right to health (positive right). Here, the right to health suffers a setback, as the private right that is sought to be balanced with it is also described as a human right, which it is not in actual terms. Thomas Pogge argues that the current international rules which are shaped by developed/wealthier countries contribute to massive deprivations among the disadvantaged, and are therefore unjust, and those responsible for the

${ }^{180}$ Mwangi (n 174) 255.

${ }^{181}$ Mwangi (n 174) 255.

182 Mwangi (n 174) 255.

${ }^{183}$ Mwangi (n 174) 255.

${ }^{184}$ Dutfield and Suthersanan (n 172) 225.

185 Dutfield and Suthersanan (n 172) 225.

${ }^{186}$ L Forman, 'Ensuring Reasonable Health: Health Rights, the Judiciary, and South African HIV/AIDS Policy' The Journal of Law, Medicine \& Ethics Vol. 33 No. 4 (2005) 711-724, 711-714. The author is of the strong opinion that the inclusion of the right to health in human rights treaties show that the right to health is a legal right, which entails obligations on States. See also P Xiong (n 152) 29.

${ }^{187}$ MA Santoro, 'Human Rights and Human Needs: Diverse Moral Principles Justifying Access' NCJ Int'l L \& Com Reg Vol. 31 (2006) 923-942, 940.

188 Ibid. See also Forman (n 186), where the author opines that right to health is a legal right, which entails obligations on the State. 
design and imposition of the said rules are not merely failing to protect human rights, but are actively violating the rights of billions. ${ }^{189} \mathrm{He}$ further urges the developed nations to work toward reform or to compensate for the harm caused.

\subsubsection{Access to Medicines as Human Right}

Improving access to affordable medicines in the developing countries and LDCs had been on the agenda of international bodies for well over four decades, resulting in the adoption of resolutions and declarations. These resolutions and declaration meant a clear commitment from developed nations and developing nations to devote time and resources to address the issue of access to medicines. In the 1980s, HIV/AIDS, a previously unknown disease, affected populations across the globe, with the most vulnerable populations coming from the developing and least developed parts of the world. While progress has been made in the treatment of the disease, it still remains inaccessible to a majority of the population who suffer from it. Those affected by HIV/AIDS but with access to the best treatment options still live in developed countries, and those with little or no access to medicines and treatment live in developing countries and LDCs. The developed countries hold the patent rights to most medicines which offer the best treatment options possible for the treatment of HIV/AIDS. By moving the protection of intellectual property rights (which importantly includes pharmaceutical patents) from the remit of the WIPO to the WTO, and extending the patent protection to 20 years, the developed countries have made access to life saving medicines even more difficult to achieve, both in the short and long term. These changes made in the late 1980s to ensure intellectual property rights protection was granted at a global level, saw the introduction of the TRIPS Agreement, which in some ways seeks to strike a balance between intellectual property rights and access to medicines. The TRIPS Agreement has instead struck a discord, and has only made access to life saving medicines an even more difficult task to achieve in developing countries and LDCs.

The clash between human rights and intellectual property is clearly epitomized by the issue of access to patented medicines. ${ }^{190}$ The problems faced in access to medicines in developing countries and LDCs have presented the stark realities of the ills of an extended international protection regime for intellectual property rights, more particularly pharmaceutical patent protection, as the cost of access to affordable medicines, as opposed to an available cure has clearly contributed to the loss of lives of innocent human beings. The developed nations who advocated the wider, global intellectual property protection at the WTO will not be affected by the rising cost of access to affordable medicines, as they do have in place a robust health care system through which they also administer the access to medicines to its citizens. For instance, in developed countries, antiretroviral drugs (ARVs) have "transformed AIDS from a death sentence to a chronic illness and saved thousands of lives," but in sharp contrast, even at the reduced price of $\$ 300$ per year the drugs remain out of reach for the 25 million Sub-Saharan Africans suffering from HIV and AIDS. ${ }^{191}$

\footnotetext{
189 T Pogge, 'Access to Medicines,' Pub Health Ethics Vol.1, No. 2 (2008) 73-82, 74.

${ }^{190}$ Helfer and Austin (n 145) 90.

191 'Paying the Price' (Television Trust for the Environment, U.S. Release 2002). <http://tve.org/films/payingthe-price/index.html $>$ accessed 22 August 2014. See also McClellan (n 190) 154. See also Dean T. Jamison et al., 'Cost-Effective Strategies for the Excess Burden of Disease in Developing Countries,' in Priorities in Health (World Bank, 2006) 59-95. <http://www.ncbi.nlm.nih.gov/books/NBK10258/> accessed 22 August 2014. The authors argue that many of the diseases and health conditions that account for a large part of the disease burden in low- and middle-income countries are far less common in high-income countries. Also, according to the authors, just eight diseases and conditions account for 29 percent of all deaths in low- and middle-income countries, namely, TB, HIV/AIDS, diarrheal diseases, vaccine-preventable diseases of childhood, malaria, respiratory infections, maternal conditions, and neonatal deaths.
} 
Unfortunately, for the AIDS patients in developing countries and LDCs, the ARVs for frontline treatment are inaccessible due to its exorbitant price, which again is fixed by transnational pharmaceutical corporations. ${ }^{192}$ The only option available in such countries is the use of affordable generics, the procurement of which in some instances has become highly problematic. ${ }^{193}$ It is also to be noted that the production and procurement of generics has almost been outlawed by the implementation of the TRIPS Agreement. Patients from developing countries and LDCs suffer most from the impact of the TRIPS, as the implementation of the Agreement has seen the price of patented drugs rise exponentially in a very short time, defying any logic.

Professor Graham Dutfield identifies poverty as the main reason for not being able to access medicines, and governments, even those that are not corrupt or otherwise woefully dysfunctional, lack the resources and infrastructure to get them to those who need medicines but cannot afford them. ${ }^{194}$ These factors, according to Dutfield, are used cleverly by the pharmaceutical industry to stave off any argument that patent rights allow them to set high prices that keep life-saving drugs out of the reach of the poor. ${ }^{195}$ In the 21 st Century globalised economy, the existence of medicines, or cure, does not guarantee their accessibility to the poor and needy in developing countries and LDCs, who were compelled to embrace an intellectual property regime under the TRIPS Agreement which is to their absolute disadvantage. The idea of withholding life-saving drugs from individuals suffering from fatal or debilitating diseases when the means exist to distribute those drugs cheaply and effectively is anathema to all notions of morality. ${ }^{196}$ Pogge refers to TRIPS as a 'notorious' Agreement, which had globalised a monopoly patent regime, which keeps the prices of advanced medicines much higher than the long-run cost of production by suppressing generic competition. He also argues that this excludes the global poor from access to vital medicines for the sake of enhancing the incentives to develop new medicines for the affluent. ${ }^{197}$ It should not be forgotten that under international human rights laws, the right to health includes elements related to healthcare - which includes access to medicines, curative and

${ }^{192}$ For the measures taken by Brazil to procure ARVs for its Anti-AIDS programme, see Sundaram (n 5). See also UNAIDS, Joint UN Programme on HIV/AIDS Staff, 2006 Report on the Global AIDS Epidemic (World Health Organization 2006) 13-14. The Report states that millions of people have died of this terrible disease 2.6 million in 2003 and 2.8 million in 2005, of which Sub-Saharan Africa contributed 1.9 million and 2.0 million respectively.

193 Sundaram (n 5);

${ }^{194}$ G Dutfield, 'Delivering Drugs to the Poor: Will the TRIPS Amendment Help' Am JL \& Med, Vol. 34 (2008) 107-124. See L Ferreira, 'Access to HIV/AID Drugs: The Human Rights Obligations of Multinational Pharmaceutical Corporations' Fordham L Rev Vol. 71 Issue 3 (2002) 1133-1180, pp.1133-1135. The author argues that poverty is a potent cause of death in developing countries with significant poor population, and that a vast proportion of patients in developing countries may die because the medicines to control the progression of diseases are unaffordable. See also EFM 't Hoen, 'TRIPS, Pharmaceutical Patents and Access to Essential Medicines: Seattle, Doha and Beyond' in Economics of AIDS and Access to HIV/AIDS Care in Developing Countries: Issues and Challenges (Agence Nationale de Recherches sur le SIDA (ANRS), 2003) 39-67. The author argues that the important reason for the lack of access to medicines in many cases is the high prices of drugs which acts as a barrier to much needed treatments, and that prohibitive drug prices are often the result of strong IP protection.

195 Ibid. See also T Jones, Commentary, in Public Health, Innovation and Intellectual Property Rights: Report of the Commission on Intellectual Property Rights, Innovation and Public Health (World Health Organization, 2006) 202, where it is observed that "Concerning access, patents are not the issue but the overwhelming poverty of individuals, absence of state healthcare financing, lack of medical personnel, transport and distribution infrastructure plus supply chain charges which can make affordable originator or generic products unaffordable. In many countries, medicines are unaffordable from whatever source, price or patent status."

${ }^{196}$ See generally Pogge (n 189).

${ }^{197}$ Pogge (n 189) 75. 
preventive health care, and other aspects related to a number of 'underlying preconditions for health.' ${ }^{198}$ In this regard the Committee on Economic, Social and Cultural Rights (CESCR) interpreted the understanding of the 'highest attainable standard of health' as "a right to the enjoyment of a variety of facilities, good, services and conditions necessary for the realisation of the highest attainable standard of health," 199 and access to necessary medicines should be understood in light of this explanation. This would mean that the 'Right to Highest Attainable Standard of Health' should include the of "provision of equal and timely access to basic preventive, curative, rehabilitative health services and health education; ...; appropriate treatment of prevalent diseases, illness, injuries and disabilities; the provision of essential drugs; and..."200 In this sense, medicines, as a basic means for the guarantee of people's enjoyment of health should be made available to ensure the realisation of the right to health, and implies that the right to health encompasses a minimum and universal right to affordable essential medicines. ${ }^{201}$

It can be argued that the developing countries and LDCs had their chance to put their cases across when the TRIPS Agreement was negotiated in the Uruguay Round of negotiations prior to its entry in 1995, and that the negative effect of the TRIPS Agreement, if any on access to medicines, were addressed by the TRIPS Council and off-set through the Doha Declaration made in 2001. Unfortunately, this argument is not sustainable, as a level playing field was glaringly absent during the Uruguay Round of negotiations (a factor discussed earlier in this article), which effectively gave away the advantage to the advocates of an international intellectual property rights protection regime. The negotiation and entry of TRIPs in 1995 empowered a particular group of actors, namely developed countries led by the US, to successfully embed their preferred way of governing IP rights in the TRIPs agreement. ${ }^{202}$ Pogge argues that the Agreement cannot be just, and highlights the fact that representatives of a number of acceding governments included individuals such as Suharto (Indonesia), Mugabe (Zimbabwe), Sani Abacha (Nigeria), Mobutu Sese Seko (Democratic Republic of Congo), and Burma's SLORC junta, who could not have represented the best interests of the people they were ruling. ${ }^{203}$ Supporting Pogge, one can argue that large democracies like India, Brazil, South Africa etc., represented by democratically elected governments, opposed the very entry of patent protection into the WTO on the grounds that the right place for matters relating to IP rights protection was the WIPO, while also warning that it could cause serious harm to the populations residing in developing countries and LDCs in their access to affordable medicines. The developing countries were in for a rude shock, when the negotiated trade-off agreed with the developed countries to sign the TRIPS Agreement did not materialise. ${ }^{204}$ Pogge also argues that by globalizing the pharmaceutical patent regime the advanced nations have imposed a very costly loss of freedom on the global

${ }^{198}$ B Toebes, 'Towards an Improved Understanding of the International Human Right to Health,' Human Rights Quarterly Vol. 21 No 3 (1999) 661-679, 665-71; See also Xiong (n 152) 23.

${ }^{199}$ See Council on Economic, Social and Cultural Rights (CESR), General Comment No 14, 22nd Sess, (4 July 2000) para 9 [Document E/C.12/2000/4].

200 Ibid.

201 M McClellan, 'Tools for Success: The TRIPS Agreement and the Human Rights to Essential Medicine' Wash \& Lee J Civi Rts \& Soc Just Vol. 12 (2005) 153-175, 160-1. The author argues that right to life and right to health determine a right to essential affordable medicines.

${ }^{202}$ V Muzaka, The Politics of Intellectual Property Rights and Access to Medicines (Palgrave, 2011) 19.

${ }^{203}$ Pogge (n 189) 76.

${ }^{204}$ RC Dreyfuss, 'The Role of India, China, Brazil and Other Emerging Economies in Establishing Access Norms for Intellectual Property and Intellectual Property Law Making' IILJ Working Paper 2009/5, NYU School of Law (2009) 4 <http://ssrn.com//aol3/papers.cfm?abstract=11442785> accessed 28 January 2014. The author points out that the trade-off was access to foreign markets in exchange for raising domestic IP levels, which was a losing proposition. 
poor, thereby cutting off poor patients from their generic drug supply and exposing billions of vulnerable people to heightened risk of death and disease. ${ }^{205}$

Stiglitz observes that while he was serving in the Council of Economic Advisors under the Clinton Administration, it was "clear that there was more interest in pleasing the pharmaceutical and entertainment industries than in ensuring an intellectual-property regime that was good for science, let alone for developing countries." ${ }^{206} \mathrm{He}$ also notes that the trade negotiators who framed the IP agreement of the Uruguay Round of negotiations in the early 1990s were "either unaware of all this, or more likely, uninterested." 207 These shocking observations sheds light on the general mood prevalent at the highest level of trade negotiation, where the framers were totally unaware of such problems of access to medicines, and also not so keen in discussing such issues. Several investigations carried out in the preWTO era had clearly demonstrated that the protection of intellectual property right is disproportionately more important to the chemical and pharmaceutical industries. ${ }^{208}$ It is obvious that at the root of the TRIPS Agreement lies the persistent tension between the economic powerhouses that seek to commodify and appropriate more intellectual goods into the private property realm and those who seek the dissemination of such intellectual goods into the 'intangible commons' for public use and the protection of the public domain more generally. ${ }^{209}$ The TRIPS Agreement and its imposition are plainly unjust and will, in terms of the magnitude of harm caused, top the ratings of the largest human rights violations in history.

A discussion on access to essential medicines will not be complete without mentioning the role of free trade agreements (FTAs), plurilateral agreements, and TRIPS-plus provisions, which have caused serious harm and also posed fresh problems. The threat to access to medicines, both actual and perceived, does not stop with the introduction of multilateral agreements which were instrumental in the introduction of a higher international intellectual property rights protection, but continues to grow with the forging of FTAs and other plurilateral agreements. These agreements cannot now be seen as a mere 'threat', as they have clearly evolved to become concrete barriers to the access to affordable medicines in developing countries and LDCs. The only international organization where such matters can now be debated is the WTO, which administers the TRIPS Agreement and other covered agreements of the multilateral trading system. The WTO, needless to say, does not have any control over the FTAs nor other plurilateral agreements affecting access to medicines in developing countries and LDCs. In this regard the loss of WIPO's governance over the administration of international intellectual property rights protection is lamentable, and the actions of the developed countries in moving the governance from the WIPO to the WTO in the late 1980s can only be seen as a calculated move to serve the interest of 'rights owning' countries. To some degree it can also be asserted that the developing countries and the LDCs have been traded off to benefit the intellectual property right holders. The US strategy on such matters has always been to directly influence and constrain the pharmaceutical coverage programmes of its trading partners. ${ }^{210}$ There is also a strong view that an 'informal empire' has been built on a legal framework by the developed countries, particularly the US, by virtue

\footnotetext{
205 T Pogge, 'Medicines for the World: Boosting Innovation Without Obstructing Free Access,' SUR - Int'l J on Hum Rts Vol. 8 (2008) 117-140.

${ }^{206}$ Stiglitz (n 132).

207 Stiglitz (n 132).

${ }^{208}$ CA Primo Braga, in WE Seibeck, (ed.), Strengthening Protection of Intellectual Property in Developing Countries: A Survey of the Literature, (Washington DC, World Bank 1990) 48.

${ }^{209}$ Muzaka (n 202).

210 See R Lopert and D Gleeson, "The High Price of "Free" Trade: US Trade Agreements and Access to Medicines' The Journal of Law, Medicine \& Ethics Vol. 41, Issue 1 (2013) 199-223.
} 
of their obvious economic supremacy, by dictating the terms of international legal rules and also at the same time interpreting the said rules in a form suitable to their own interests without any realistic challenge. ${ }^{211}$

If the TRIPS Agreement was a well concerted effort by the developed countries and their transnational pharmaceutical corporations, then, the TRIPS Agreement flexibilities and the Doha Declaration were a hard fought bargain by the developing countries, LDCs and NGOs. One of the main concerns for some of the developing countries during the negotiations was the requirement of a sudden transition from a process patent regime to a product patent regime. The TRIPS Flexibilities were built into the TRIPS Agreement to benefit the developing countries and LDCs while implementing the Agreement into their national laws. This was intended to take away the strain of imposing a higher intellectual property rights regime upon jurisdictions which were not fully prepared to embrace a much higher standard than the one in place in the domestic legislation. As discussed earlier the TRIPS flexibilities afforded a delayed implementation, the use of compulsory licensing, etc., but in actual practice it had been extremely difficult, or even impossible, for the developing countries to implement. A combination of factors, namely, the TRIPS-plus provisions introduced through FTAs, political pressure from developed countries through trade sanctions, and pressure from transnational pharmaceutical companies - either through protracted court proceedings, and or lobbying, have robbed the developing countries and the LDCs from exercising their rights under the TRIPS Agreement. It can be argued that pharmaceutical patent holding developed countries have used the TRIPS Agreement to effectively set a bench-mark on intellectual property standards and have exploited the loopholes in the multilateral trading system, which allows for regional trade agreements, to effectively prevent the developing countries from implementing the TRIPS flexibilities.

\subsubsection{Implementation of Paragraph 6 and the Proposal for Amendments}

It would be pertinent here to discuss the implementation of paragraph 6 of the Doha Declaration and the proposed amendments to the Agreement made in 2005. Many developing countries and LDCs do not have the manufacturing capacity and, or the economic viability to either produce active ingredients, or formulations, and hence cannot avail the provision of 'compulsory licenses' under the TRIPS Agreement. Also, the option of importing generic medicines from other countries is restricted in the Agreement which requires production under compulsory licence to be predominantly for the supply of the domestic market. Paragraph 6 of the Doha Declaration reads as follows: "WTO members with insufficient or no manufacturing capacities in the pharmaceutical sector could face difficulties in making effective use of compulsory licensing under the TRIPS Agreement." Recognizing the problem, the Doha Declaration directed the Council for TRIPS to find an expeditious solution and to report back to the General Council before the end of 2002. After nearly two years of negotiations, on 30 August, 2003, ${ }^{212}$ the General Council of the WTO finally adopted the Decision on Implementation of paragraph 6 of the Doha Declaration on the TRIPS Agreement and Public Health (the August Decision). The paragraph 6 solution is essentially an interim waiver with regard to the obligations under 31 (f) and (h) ${ }^{213}$ of the TRIPS

${ }^{211}$ A Rahmatian, 'Neo-Colonial Aspects of Global IP Protection' The Journal of World Intellectual Property Vol. 12, No. 1 (2009) 40-74, 47.

${ }^{212}$ Implementation of Paragraph 6 of the Doha Declaration on the TRIPS Agreement and Public Health WT/L/540 (30 August 2003) <http://www.wto.org/english/tratop_e/trips_e/implem_para6_e.htm> accessed 1 August 2014.

${ }^{213}$ Article 31 - Other Use Without Authorization of the Right Holder: Where the law of a Member allows for other use of the subject matter of a patent without the authorization of the right holder, including use by the government or third parties authorized by the government, the following provisions shall be respected:...(f) any 
Agreement, which allows for the total quantity of drugs produced under a compulsory licence to be exported. Any implementation of the Decision will require carrying out changes to national laws, and also ensuring that countries do not assume TRIPS-plus obligations under bilateral or regional trade agreements (RTAs). ${ }^{214}$ Since August 2003, the Council for TRIPS had met annually to review the implementation of Paragraph 6 of the Doha Declaration, and as per paragraph 8 , "with a view to ensuring its effective operation, and shall annually report on its operation to the General Council." This waiver under paragraph 6 shall terminate on the date on which an amendment to the TRIPS Agreement replacing its provisions takes effect for a member. ${ }^{215}$ However, on 6 December 2005 the WTO Member States reached an agreement on the amendment to the TRIPS Agreement. ${ }^{216}$ This proposal, if and when given effect to, will make the temporary waiver of Article 31(f) of the Decision taken on 30 August 2003, a permanent feature. Any decision to review the TRIPS Agreement can only be enforced if the protocol to amend the Agreement is accepted by a two third majority of the Member States, and the said Protocol will be kept open for acceptance by Member States until 31 December 2015.

With almost a year to go, only 53 Member States (as of 31 July 2014) have desired an amendment of the Agreement. ${ }^{217}$ This in itself is a worrying development, as a number of developing countries and LDCs who are being affected, and will be affected even more in the coming months and years, have not expressed their wish for an amendment to the Agreement. Given the fact what is sought to be made permanent is the temporary waiver brought under paragraph 6 of the Doha Declaration, which will pave the way for exporting and importing generic drugs under the compulsory licensing provision of the TRIPS Agreement it is a real concern that there is very little engagement in this regard from the developing countries and LDCs. This clearly demonstrates, not an indifference towards the issue, but an ignorance of the magnitude of the problem that the TRIPS Agreement had brought about in the access to medicines in the developing countries and LDCs. This takes us back to a point made earlier if there had been a level playing field at the Uruguay Round of negotiations when the TRIPS was taken up for discussions; and all the Ministerial representatives at the GATT conversant

such use shall be authorized predominantly for the supply of the domestic market of the Member authorizing such use,....; (h) the right holder shall be paid adequate remuneration in the circumstances of each case, taking into account the economic value of the authorization.

214 See CM Correa, 'Implementation of the WTO General Council Decision on Paragraph 6 of the Doha Declaration on the TRIPS Agreement and Public Health,' Essential Drugs and Medicines Policy, (WHO, 2004)

7. <http://apps.who.int/iris/bitstream/10665/68743/1/WHO_EDM_PAR_2004.4_(2).pdf?ua=1> accessed 14 August 2014. The author notes that bilateral agreements established by the US with some developing and developed countries (e.g., Australia, the Central American countries, Chile, Jordan, Morocco) require the protection of data under a sui generis regime of data exclusivity for at least five years from the date of the first approval of a pharmaceutical product in the country.

${ }^{215}$ A waiver in this regard does not imply any change of substantive treaty obligations; it only temporarily suspends their operation (Article 57 of the Vienna Convention on the Law of Treaties). A WTO waiver means that a Member shall not initiate a complaint against another Member if the latter acted under the terms of the adopted waiver. However, to the extent that a Member's national law is not revised to implement the terms of the waiver; patent owners may invoke provisions in the national law to block the export of a patented drug by other companies. See also Correa (214); D Matthews, 'WTO Decision on Implementation of Paragraph 6 of the DOHA Declaration on the TRIPs Agreement and Public Health: A Solution to the Access to Essential Medicines Problem?' Journal of International Economic Law Vol. 7 No.1 (2004): 73-107.

${ }^{216}$ Amendment of the TRIPS Agreement: Decision of 6 December 2005, World Trade Organization [WT/L/641 8 December 2005]. It is to be noted that the TRIPS Agreement had never been amendment since its entry on 1 January 1995.

217 See INTELLECTUAL PROPERTY: TRIPS AND PUBLIC HEALTH, 'Members Accepting Amendment of the TRIPS Agreement,' WTO (2014) <http://www.wto.org/english/tratop_e/trips_e/amendment_e.htm> accessed 31 August 2014. 
and aware of the shortcoming of the proposal that was being negotiated, there would not have been an agreement on an enlarged international intellectual property rights protection regime through the WTO. Most of the sub-Saharan African countries suffer due to lack of access to medicines, but a mere 6 Member States have expressed their desire for an amendment. ${ }^{218}$ Sadly, a majority of the countries in sub-Saharan Africa rely on generic drugs for treatment, and do not possess the necessary infrastructure to manufacture any generic drugs that they need for frontline treatment. Africa as a continent will stand to benefit through a full support of the amendment to the TRIPS Agreement from its WTO Member States. It is yet to be seen if the 31 December 2015 deadline will come to pass, or if the proposed amendment, as in the past, will get another extension.

\subsubsection{Transnational Pharmaceutical Corporations \& the Right to Life Saving Medicines}

From the foregoing discussion one can conclude that the key player behind the creation of a global intellectual property rights protection was the transnational pharmaceutical corporations who hold patent rights to pharmaceutical patents for the medicines required in the treatment of diseases in the world. Importantly, the consumers of patented pharmaceutical goods are spread all over the world, and more so in the developing countries and LDCs. Patients in developing countries and LDCs suffer most from the impact of the TRIPS Agreement, as the implementation has seen the price of patented drugs rise exponentially within a very short time, defying any logic. This situation has resulted in medicines becoming unaffordable and beyond the reach of even governmental agencies in developing countries and LDCs. As mentioned earlier, the most affected patients of the HIV/AIDS pandemic come from developing countries or LDCs where frontline treatment is unaffordable due to the above factor. Stiglitz argues that one of the reasons for high costs of medicines ".. is that the patent system impedes access to lifesaving drugs for billions." 219 Stiglitz also argues that one of the main reasons the transnational pharmaceutical industry was pushing for TRIPS was that they wanted to reduce access to generic medicines, as the prices of generic drugs are very low and are favoured over the much higher priced patented drugs. ${ }^{220}$ And also, any competition with the generics drugs will drive down the price of the brand name drugs. Stiglitz observes that the lower prices in turn lowers the profits of the brand name pharmaceutical companies, and that it is understandable why the transnational pharmaceutical corporations pushed so hard and also contributed for international IP rights protection. ${ }^{221}$

Patients in developed countries do not face a similar fate, as they boast of a welldefined health care system, where medicines are affordable (through prescriptions), and also medical treatment is well regulated by their respective governments. The same cannot be said about any of the developing countries or LDCs. The voice from the developing countries that we hear is not for free medicine but for the access to affordable medicines. It should be seen as the failure of the WTO to develop an adequate solution to the AIDS issue which is emblematic of a broader truth about global intellectual property rights and the developing world. ${ }^{222}$ To a greater degree, the WTO, as an agency of the United Nations (UN) and the

\footnotetext{
${ }^{218}$ Ibid. It should be noted that the African Continent is still in the grip of HIV/AIDS and most number of deaths are still reported in Africa than in any other Continent in the world. The non-availability of affordable ARVs still remains as the main problem in the fight against HIV/AIDS.

219 J Stiglitz, 'Economic Foundations of Intellectual Property Rights’ Duke Law Journal Vol. 57 (2008) 1693$1724,1701$.

220 Ibid.

221 Ibid.

222 P Drahos and J Braithwaite, 'Three Tests of US Trade Policy on Intellectual Property Rights', Nth Position (July 2003) <http://www.nthposition.com/threetestsofustrade.php> accessed 31 May 2014.
} 
world governing body that administers the TRIPS Agreement, should be made accountable in its failure in not finding an effective solution to access to medicines in most of its Member States, and more particularly in developing countries and LDCs, where patent protection is compulsorily extended to pharmaceutical products through the TRIPS Agreement. The argument that Doha declaration was especially formulated to address this issue, and that flexibilities were built into the TRIPS Agreement to address the specific issue cannot be sustained, as they have proven to be ineffective in most cases. As Stiglitz observes the transnational pharmaceutical corporations and FTAs have made the grant of compulsory licenses difficult. He further argues that "had the intention been to retain access to lifesaving generic medicines for developing countries, TRIPS would have provided for an automatic right to issue compulsory licenses for expensive, life-saving medicines." 223 In his opinion when the trade ministers signed the TRIPS Agreement "....in the spring of 1994, they were in effect signing the death warrants on thousands of people in sub-Saharan Africa and elsewhere in the developing countries." 224 Sherry Marcellin notes that the making of the patent provision under TRIPS Agreement represents an instance of institutional capture by private interests, dominated by American industry. ${ }^{225}$

A thorough study of the actual investment into research and development (R\&D), marketing and the cost of patented drugs offered for sale by transnational pharmaceutical corporations in developing countries is to be undertaken to have a clear picture of the cost benefit ratio of the research, investment, the cost of production and benefit derived by the end user. This again is subject to data being made available by the by transnational pharmaceutical corporations. Worryingly, there is a lack of transparency in the pharmaceutical business sector, and also the fact transnational pharmaceutical corporations take advantage of the loopholes in the international legal system to conceal valuable data from public scrutiny makes it harder for a study. Any report available from such a study will have the potential to challenge the argument of 'patents encourage innovation in the medical sector' used to justify the pharmaceutical corporations. Pharmaceutical industry representatives have long defended patents rights as the 'lifeblood of our industry - we literally could not exist without them. ${ }^{226}$ Given the great importance the transnational pharmaceutical sector places on patents, it is not surprising that it stands alone in its involvement with the patent system and also has done much to ensure that the system meets its requirements. ${ }^{227}$ According to Lipton, the patent driven approach in the pharmaceutical industry has been linked to healthcare access in developing countries in that the costs of pharmaceutical products, directly or indirectly increase the national budget of developing countries for medicines "... and constitute a hindrance to the effective provision of health care by public authorities." 228 Some have even argued that since disease impairs normal human functioning, it restricts a person's range of opportunities to pursue a career, and that by preventing, curing, or ameliorating disease, therefore, adequate health care helps to guarantee fair equality of opportunity. ${ }^{29}$ Most importantly, the current commercial patent model as

${ }^{223}$ Stiglitz (n 208).

${ }^{224}$ Stiglitz (n 208).

${ }^{225}$ Marcellin (n 107) 13.

${ }^{226} \mathrm{~J}$ Braun, and MP Pugatch. 'The changing face of the pharmaceutical industry and intellectual property rights,' The Journal of World Intellectual Property Vol. 8 Issue 5 (2005) 599-623, 604.

${ }^{227}$ S Macdonald, 'Exploring the Hidden Costs of Patents' in P Drahos and R Mayne (eds) Global Intellectual Property Rights: Knowledge Access and Development (Palgrave MacMillan 2002).

${ }^{228}$ M Lipton, 'Bottom Billion: Countries or People?' The Journal of Development Studies Vol. 44 Issue 5 (2008) $750-760$.

${ }^{229}$ N Daniels, 'Health Care Needs and Distributive Justice,' Philosophy \& Public Affairs Vol. 10, No. 2 (1981) 146-179, 158-160; See also JC Moskop, 'Rawlsian Justice and a Human Right to Health Care,' J Med \& Phil 
practiced by the pharmaceutical industry results in a gross inadequacy of appropriate R\&D for medicines and vaccines required to tackle diseases that may be peculiar to developing countries. ${ }^{230}$ Stiglitz and Jayadev argue that the major problem with the current private property model of patenting prohibiting the existence of rival products without the permission of the patent right holder is that it can act as a barrier to knowledge and slow down the pace of new and socially desirable discoveries. ${ }^{231}$ This observation defeats the argument for extending pharmaceutical patent protection in developing countries and LDCs as very little $\mathrm{R} \& \mathrm{D}$ is carried out by transnational pharmaceutical corporations into diseases prevalent in developing countries and LDCs.

Patent holding transnational pharmaceutical corporations are viewed as complex organisations which exceed their goals and functions, but in non-utilitarian ways. ${ }^{232}$ Umahi and Osuji observe that transnational pharmaceutical corporations are seen as a major impediment to access to essential lifesaving medicines in developing countries. ${ }^{233}$ In their view Article $27^{234}$ of the TRIPS Agreement lays down a very wide primary provision that creates exclusive rights affecting virtually every aspect of the availability and affordability of medicines. As observed by Justice Jacobs, such exclusive rights prop "an arms race in which the weapons are patents." ${ }^{235}$ A judicial observation from Justice Jacobs in the above lines is a damnifying verdict on the global patent system. In Umahi and Osuji's opinion it is a race which developing countries lack the capacity to compete in effectively, as they try to protect the interests of the consumers of pharmaceutical processes and products. The authors propose as a way-forward the creation of an effective access to medicines corporate social responsibility (CSR) ${ }^{236}$ framework for pharmaceutical companies which could include pricing, patents, testing and clinical trials, research and development, joint public private initiative and appropriate use of drugs. They also argue that the CSR of multinational pharmaceutical companies in developing countries should reflect context, opportunity, proximity, time and impact in accordance with the social integration and ethical approaches to $\mathrm{CSR}^{237}$ These suggestions go a long way in approaching the inequalities created by the

Vol. 8 (1983) 329-338. See also N Daniels et al., ‘An Ethical Template for Pharmacy Benefits,' Health Affairs Vol. 22, No. 1 (2003) 125-137, where the author is concerned with the question of how governments and health maintenance organizations with limited resources should allocate scarce resources among competing health priorities.

${ }^{230} \mathrm{~J}$ Lexchin, 'One step forward, one step sideways? Expanding research capacity for neglected diseases', $B M C$ International Health and Human Rights 10(20) (2010) 1-10.

231 JE Stiglitz and A Jayadev, 'Medicines for Tomorrow: Alternative Proposals to Promote Socially beneficial Research' Journal of Generic Medicines: The Business Journal for the Generic Medicines Sector Vol. 7, Issue 3 (2010) 217-226.

232 R Palan, 'New trends in global political economy', in R Palan (ed.) Global Political Economy: Contemporary Theories (Routledge, 2000) 1-18, 15.

233 OT Umahi and OK Osuji, 'Pharmaceutical Companies and Access to Medicines - Social Integration and Ethical CSR Resolution of a Global Public Choice Problem' Journal of Global Ethics Vol. 8, Issue 2-3 (2012) 139-167.

${ }^{234}$ Article 27.1: Subject to the provisions of paragraphs 2 and 3, patents shall be available for any inventions, whether products or processes, in all fields of technology, provided that they are new, involve an inventive step and are capable of industrial application. Subject to paragraph 4 of Article 65, paragraph 8 of Article 70 and paragraph 3 of this Article, patents shall be available and patent rights enjoyable without discrimination as to the place of invention, the field of technology and whether products are imported or locally produced.

${ }^{235}$ Aerotel $v$ Telco, In Re Patent Application in the Name of Macrossan [2006] EWCA Civ. 1371, para.18

${ }^{236}$ Although CSR partly overlaps and complement business ethics, there are still significant differences between the two. While business ethics is a well-established research stream, CSR as a conceptual level deals with the role of business in society and its responsibility towards its stakeholders and as well as to society. CSR does not stop with the traditional model of business responsibility to shareholders and secondary stakeholders.

${ }^{237}$ Umahi and Osuji (n 222). 
implementation of the TRIPS Agreement. Sadly, what we are witnessing is a modern day David and Goliath situation, where diminutive David is losing out fast against the patent holding pharmaceutical giant, Goliath.

\section{PART 4}

\subsection{Findings}

The neoclassical worldview that what is good for business is also good for the society is not sustainable, as the economic foundations of the patent system, or the justification for a monopoly protection for private rights at the cost of public good and human rights is illfounded. Jagdish Bhagwati, the renowned economist and an advocate of free-trade, argues that the TRIPS Agreement does not belong in the WTO, as it enforces payment by the poor countries (consumers) to the rich countries (intellectual property producers), and that by introducing the TRIPS through the WTO "we legitimated the WTO to extract royalty payments." ${ }^{238}$ Bhagwati, declaring support for the NGO statement 'asking for the IP leg of the WTO to be sawn off,' also observed that the WTO must be about mutual gains in trade, but whereas intellectual property protection, introduced through the TRIPS Agreement, is a tax on poor countries, constituting a wealth transfer to the rich countries, that has turned the WTO into a royalty-collection agency. ${ }^{239}$ As observed by Stiglitz, the importance of intellectual property rights are exaggerated, and they form only one part of our innovation system, and that they should be seen "as part of a portfolio of instruments." 240 Stiglitz further argues that there is an immediate need to strengthen the other elements of this portfolio and redesign the current intellectual property regime to increase its benefits and reduce its costs. Martin Khor, while advocating for a review of the TRIPS Agreement, argues that the agenda should include the "question of its removal from the WTO so that the trade organisation can return to its mission of promoting balanced trade options." 241

Earlier in the discussion, it was noted how transnational corporations led by patent holding pharmaceutical corporations, and ably backed by developed countries successfully shifted the forum for international intellectual property rights protection from the WIPO to the WTO during the Uruguay Round of negotiations. Not stopping with the shift in the forum, as argued by Marcellin, ${ }^{242}$ the patent holding pharmaceutical corporations through the developed country representation have resorted to an 'institutional capture,' which in effect had resulted in a stalemate with the no possibility of a renegotiation of the TRIPS Agreement at the WTO. Not only have the transnational patent holding corporations been successful in shifting the forum from the WIPO to the WTO and in the eventual creation of the TRIPS Agreement, but also taking absolute control of the administering body through the developed country Member States. In the foregoing paragraphs we discussed the access to medicines/public health implications of an enforced international intellectual property rights protection regime on the Member States of the WTO, and also there being no real consensus

\footnotetext{
238 J Bhagwati, 'Afterword: The Question of Linkage,' American Journal of International Law Vol. 96 Issue 1 (2002) 126-134, 127.

239 J Bhagwati, Letter to The Editor, Financial Times (14 February 2001) $<$ www.columbia.edu/ jb38/papers/pdf/FT_Letter_on_IPP.pdf $>$ accessed 21 August 2014. See also M Khor, 'Rethinking Intellectual Property Rights and TRIPS' in P Drahos and R Mayne (eds.) Global Intellectual Property Rights: Knowledge, Access and Development (Palgrave Macmillan 2002) 201-13, 212.

240 JE Stiglitz, 'Economic Foundations of Intellectual Property Rights', Duke Law Journal (2008) 1693-1724, 1724.

${ }^{241}$ Khor (n 239).

242 Marcellin (n 107).
} 
as to the impact of patent protection on the growth of technology. ${ }^{243}$ Instead of engaging in a debate if the intellectual property rights protection will lead to increased innovation and foreign investment in developing countries, ${ }^{244}$ or if current drug prices are justified by the need for future research and development, ${ }^{245}$ it would be hugely beneficial to engage in a serious study of the harms of an expanded international intellectual property rights protection on global public health concerns as a human right. The need of the hour is a thorough examination of the philosophical foundations for an international intellectual property rights $v i s-\grave{a}$-vis that of the foundations to public right to health, as the utilitarian basis of intellectual property rights protection seem to completely neglect the rights of the individual to the enjoyment of the public good.

\subsection{Discussion and Conclusion}

The economic analysis of intellectual property laws are inconclusive as regards their benefit to society, as there is a division in the perception of what is public good, and if intellectual property would constitute a public good. From the above discussion, it is that the current international intellectual property regime, which is modelled on the US intellectual property laws, and as promoted by the WTO through the TRIPS Agreement, has caused and continues to cause enormous difficulties for the developing countries and LDCs through its implementation. The TRIPS Agreement's implementation has also helped the pharmaceutical corporations to create a false demand and increase the price of patented pharmaceutical products. This raises the question if the international intellectual property regime's economic justification to society's welfare has been overstated and overshadows the harm it causes to societies in developed countries and LDCs. What is clear, though is that under the current regime, information is patentable (also heavily patented), and comes at a very high price, and consumers you pay tax and royalty to the developed countries on everything one consumes on a daily basis. Information is knowledge, and it does not come free but at a high price. This leads us to the question, if it was at all necessary for the WTO to move towards a global product patent regime in the first place? As discussed earlier, the idea or, more precisely the template was mooted by transnational pharmaceutical corporations ably backed by other patent holding corporations and developed countries to move towards a product patent regime. This model was designed to create a two tier system, which comprises the patent holders and consumers amongst the WTO Member States, where the globally spread consumers (mostly located in developing countries and LDCs) pay a royalty to the patent holders based in developed countries. The TRIPS regime also effectively outlaws the generic drugs industry through the introduction of a product patent system, which had been the mainstay for developing countries and LDCs, offering access to affordable medicine for their health care needs. It is well documented that transnational pharmaceutical corporations have hindered the movement of generic drugs through the misuse of EU regulations in the past, ${ }^{246}$ although there was nothing to prove that the generic drugs transported violated any existing patent laws. In the post-TRIPS era, the transnational pharmaceutical corporations have

\footnotetext{
${ }^{243}$ EW Kitch, 'Patents: Monopolies Or Property Rights?' Research In Law \& Economics, Vol. 8 (1986) 31-49.

${ }^{244}$ Robert. Sherwood, 'A Larger Context for Considering Pharmaceutical Patents in Developing Countries,' 15 World Bull 76 (January-December 1999) (Institute of International Legal Studies, University of Philippines Law Center), as cited by H Klug, 'Comment: Access to Essential Medicines - Promoting Human Rights Over Free Trade and Intellectual Property Claims, in KE Maskus and JH Reichman (eds.) International Public Goods and Transfer of Technology Under a Globalized Intellectual Property Regime (Cambridge, 2005) 482.

${ }^{245}$ H.E. Bale, 'Patent Protection and Pharmaceutical Innovation,' NYUJ Int'l L \& Pol., Vol. 29 (1997) 95. See also H Grabowski, 'Patents, Innovation and Access to New Pharmaceuticals,' Journal of International Economic Law, Vol. 5 Issue 4 (2002) 849-860.

246 Sundaram (n 5); Sundaram (n 39); Drahos and Braithwaite (n 57).
} 
challenged such TRIPS compliant legislations sought to be implemented in developing countries (through the backing of developed countries), which they view as being harmful to their business interests. ${ }^{247}$ These actions were resorted to, both before the respective domestic courts in the developing countries and before the WTO through developed country representation. These tactics have resulted in delaying the introduction of TRIPS compliant patent legislation or, thwarting the introduction of suitable legislation for growth and for implementation of health care policies in the developing countries.

The argument that intellectual property rights are important for the society will become unacceptable if the right to access to affordable medicine is not addressed by the WTO immediately. Soon, the LDCs too will be required to implement the TRIPS Agreement, thereby presenting a much more acute problem than what is being faced at the moment. The model of multilateral trade promoted and practiced under the WTO through the covered agreements is such that, it does not allow the WTO to either contain, or to respond quickly to any social inequalities created by the operation of the covered agreements. This is well demonstrated by the fact that the WTO has no control over transnational pharmaceutical corporations, who have the developed countries as their mouthpiece, or over developed countries that enter into FTAs with strong TRIPS-plus provisions. Further, it is not possible for the WTO to check the proliferation of FTAs and RTAs as they are not prohibited under the GATT, but the Member States are only obligated to declare/notify the creation of RTAs. The developing countries are caught between a rock and a hard place in their struggle to gain access to affordable medicine. What we witness is an international organisation, whose institution is not capable of addressing issues of urgent and absolute importance at a war footing. Although the above study focuses more on the problems surrounding pharmaceutical patents and access to medicines, the conclusions that one is tempted to draw is that the current global intellectual property regime as designed and introduced under the TRIPS Agreement is only capable of benefitting the patent holding developed Member States of the WTO and of great disadvantage to the non-patent holding developing country and LDC Member States of the WTO.

What one has to note is that intellectual property rights through its close association with the growth of technology and the media holds a popular position and has been glamorised by its proponents. Unfortunately, human rights and related issues do not enjoy the same luxury that intellectual property rights enjoy. Human rights has come to be associated with images of the poor and suffering in the third world, and may not have the same glamour or public appeal as intellectual property rights. The topic of HIV/AIDS is not anymore frontline news in developed countries, as it is treatable and manageable with frontline ARVs, but in sharp contrast it is a day-to-day problem in developing countries and LDCs where access to frontline ARV treatment is unaffordable as the pharmaceutical patents are held by transnational pharmaceutical corporations from one of the developed countries. It should be borne in mind that the losses that developing countries and LDCs suffer as a result of the international intellectual property rights protection does not stop with access to affordable medicines, but include issues such as access to cultural and educational material, patented seeds and food products, protection of traditional knowledge and indigenous materials, computer software, and knowledge per se. As Professor Peter Yu notes, the difference between lack of access to medicines and the lack of access to cultural and educational

\footnotetext{
${ }^{247}$ Sundaram (n 39); Sundaram (n 5); Drahos and Braithwaite (n 57). The US Trade Representative (USTR) also used the Super 301 effectively to exert pressure on the said developing countries to support the actions of the transnational pharmaceutical corporations.
} 
materials is "like the difference between dying now and dying slowly later." 248 On the aforementioned discussions and on the strength of available evidence, it is high time for a complete rethink on the TRIPS Agreement as a covered agreement of the WTO, if not as an immediate measure to remove its application to pharmaceutical patents. In the absence of a positive action on the part of the WTO to revise the TRIPS Agreement, or in the alternative to remove pharmaceutical patent protection from the ambit of TRIPS, as a way forward, the BRIC countries, the LDCs and similar interest groups should form working groups/FTAs to promote and safeguard their interests.

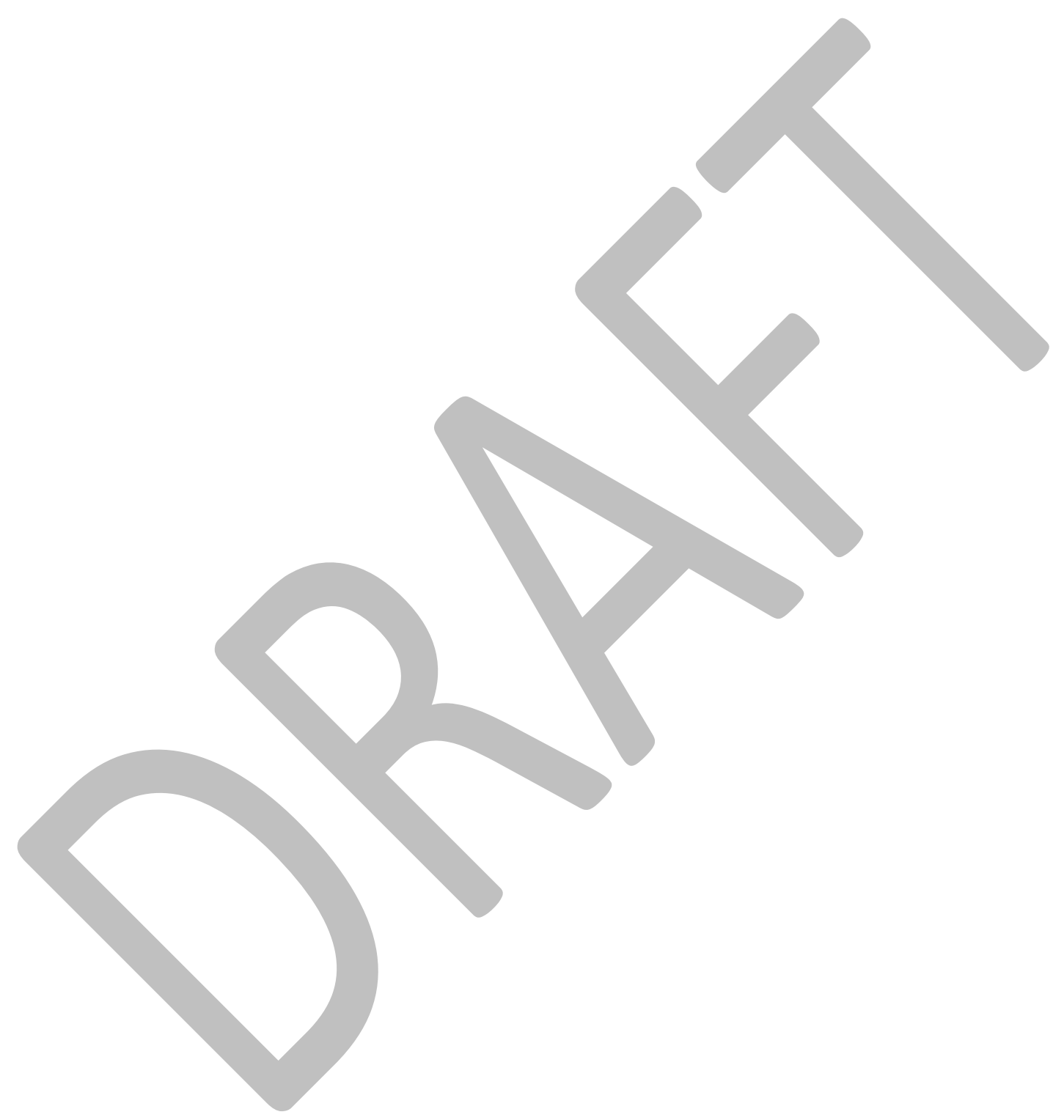

${ }^{248}$ PK Yu, 'Ten Common Question About Intellectual Property and Human Rights' Ga St UL Rev Vol. 23 Issue 4 (2007) 709-753, 719. 


\section{Email Acceptance Article 3}

From: INDIRA CARR <imcarr@btinternet.com>

Reply to: INDIRA CARR <imcarr@btinternet.com>

Date: Monday, 1 December 2014 at 09:55

To: Jae Sundaram <jae.sundaram@buckingham.ac.uk>

Subject: Re: Article - First Draft

Hello Jae,

That will be fine.

Best,

Indira

From: Jae Sundaram <jae.sundaram@buckingham.ac.uk>

To: 'INDIRA CARR' <imcarr@btinternet.com>

Sent: Monday, 1 December 2014, 9:32

Subject: RE: Article - First Draft

Dear Indira

Many thanks for the message.

I will definitely look into the draft [2a] in more detail and carry out necessary corrections. I am in the middle of marking (our exams started on Saturday...), and I should be able to get back to you by next week. Will this be fine, or do you need it earlier? Please let me know.

Best

Jae

From: INDIRA CARR [mailto:imcarr@btinternet.com]

Sent: 30 November 2014 16:49

To: Jae Sundaram

Subject: Re: Article - First Draft

Dear Jae,

Version 2a was the one that was reviewed. A number of typos and syntax errors were notices. the paper is a good introduction to the philosophical debates surrounding TRIPs. I would be very pleased to publish it in ICTL but I would like you at go through the paper including the footnotes and send me a corrected version.

Apologies for the delay.

Many thanks and best wishes,

Indira 
From: Jae Sundaram <jae.sundaram@buckingham.ac.uk>

To: "imcarr@btinternet.com" <imcarr@btinternet.com>

Sent: Thursday, 11 September 2014, 17:23

Subject: RE: Article - First Draft

Dear Indira

Please find attached a more updated version of the article where I have carried out some corrections (but have not added any more footnotes). Please let me know of your thoughts.

Best regards

Jae

From: Jae Sundaram

Sent: 03 September 2014 11:57

To: 'Indira Carr'

Subject: Article - First Draft

Dear Indira

I hope you are doing fine. I am attaching two copies of my first draft of the article I have been working on. Please let me know of your thoughts.

Best regards

Jae

University of Buckingham - Leading the National Student Survey since 2006 